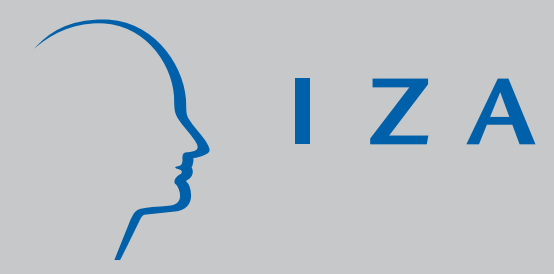

IZA DP No. 1587

Privatization Discontent and Its Determinants: Evidence from Latin America

Daniele Checchi

Massimo Florio

J orge Carrera

May 2005 


\title{
Privatization Discontent and Its Determinants: Evidence from Latin America
}

\author{
Daniele Checchi \\ University of Milan \\ and IZA Bonn
}

Massimo Florio

University of Milan

Jorge Carrera

University of La Plata

\author{
Discussion Paper No. 1587 \\ May 2005 \\ (revised July 2006) \\ IZA \\ P.O. Box 7240 \\ 53072 Bonn \\ Germany
}

Phone: +49-228-3894-0

Fax: +49-228-3894-180

Email: iza@iza.org

\begin{abstract}
Any opinions expressed here are those of the author(s) and not those of the institute. Research disseminated by IZA may include views on policy, but the institute itself takes no institutional policy positions.

The Institute for the Study of Labor (IZA) in Bonn is a local and virtual international research center and a place of communication between science, politics and business. IZA is an independent nonprofit company supported by Deutsche Post World Net. The center is associated with the University of Bonn and offers a stimulating research environment through its research networks, research support, and visitors and doctoral programs. IZA engages in (i) original and internationally competitive research in all fields of labor economics, (ii) development of policy concepts, and (iii) dissemination of research results and concepts to the interested public.
\end{abstract}

IZA Discussion Papers often represent preliminary work and are circulated to encourage discussion. Citation of such a paper should account for its provisional character. A revised version may be available directly from the author. 


\section{ABSTRACT \\ Privatization Discontent and Its Determinants: Evidence from Latin America}

Privatization policy faces increasing popular opposition in Latin America. After a discussion of recent empirical literature on this topic, we ask two simple questions: Who are the people most dissatisfied with privatization? and: Why are they dissatisfied? To answer, we use social attitudes combined with objective controls at country level. The former include the results of three waves of Latinobarometro surveys (51,635 observations, 1998, 2000 and 2002, in 17 countries). The latter include privatization data and macroeconomic variables. The data on country-specific experiences of privatization come from two different data-set. One data set exploits information about 340 divestitures occurred in Latin American countries, over the period 1990-2001. The second includes 923 infrastructure projects with private participation (including divestitures, concessions and other contracts) over the period 1984-2002. We test several empirical models and we find that disagreement with privatization is most likely when the respondent is poor, privatization was large and quick, involved a high proportion of public services as water and electricity, in countries where there is high inequality of incomes. A robust non-linear relationship between socio-economic status and dissatisfaction with privatization suggests that particularly middle-to-low income households, with a median level of nine years of education, perceive to have suffered from privatization. While misperceptions cannot be ruled out, this result is broadly consistent with recent empirical research in Latin America that points to distributional concerns in the implementation of privatization policy because of tariff rebalancing not adequately addressed by policy makers and regulators.

JEL Classification: H32, G14, L33

Keywords: privatization, Latin America, distributive impact, panel survey data, social attitudes

Corresponding author:

Massimo Florio

Department of Economics

University of Milan

Via Conservatorio 7

20122 Milan

Italy

Email: Massimo.Florio@unimi.it 


\section{Introduction}

During the last two decades privatization in Latin America (LA), and the related (usually subsequent) market liberalization and regulatory reforms, were ubiquitous policies that changed the provision of public services for millions of users. Among developing countries, Latin America was the region where privatization started earlier and generated cash proceeds for the public budgets larger than in any other region (Lora, 2001).

Despite the widespread consensus among policy-makers and international lenders ${ }^{1}$, and strong support by many economists (Chong and Lopez-de-Silanes, 2003) privatization is however highly and increasingly unpopular in Latin America, as well documented by several independent surveys (Lora, Panizza, and Quispe-Agnoli, 2004). In this paper, after a review of some recent empirical literature on this topic, we ask two simple questions: Who are the people most dissatisfied with privatization? and: Why are they dissatisfied? To address these questions we use social attitudes data, combined with objective control variables at country level.

According to strand of recent empirical research on welfare changes for consumers in Latin America (Ugaz and Waddams Price, 2003) ${ }^{2}$, distributive issues do play a role in the perception of the benefits and costs of privatization. We do not assume that respondents to surveys are always well informed, but we think that variations in their opinions, combined with objective control variables at individual and country level, including privatization characteristics, may be revealing about the information they consider. Thus, the paper focuses particularly on the contribution that the empirical analysis of subjective perceptions can offer as a complement to more traditional research on social welfare effects of policy reforms, typically based on household expenditure surveys, price trends, and other objective data.

The following quotations from recent papers set our research questions in the context of the current policy debate on utility reform.

"The supposed failure of privatization in Latin America has recently become the source of street riots, protest demonstrations, and adverse news coverage...These adverse opinions are not restricted to a handful of protesters. Latinobarometer opinion polls .. show that a clear majority disapprove of the privatization process, a pattern that is uniform across countries, age, gender and socioeconomic classes. The opinions appear to be becoming increasingly adverse over time..." (McKenzie and Mookherjee 2003,p.1-2);

"There can be little doubt that mistakes have been made and promises not kept - but a good number are not. An argument can be made that the concrete outcomes of privatization have been better than people think, or that privatization may not be the actual cause of the real difficulties they perceive. Nonetheless, perceptions count greatly in and of themselves if they result in political opposition sufficient to slow, halt or reverse a process that would bring efficiency and growth gains to a society gains which could in principle be fairly shared using tax or other policy instruments." (Birdsall and Nellis 2003, p.4);

\footnotetext{
1 According to Williamson $(1990,2000)$ privatization was a key ingredient of structural adjustment in Latin American in the framework of the Washington Consensus, i.e. the policy package advocated in the 1980s by the US Treasury, the IMF, the World Bank, and other international organizations.

${ }^{2}$ Most of the empirical privatization literature recurs to simple microeconomic performance indicators; particularly they focus on changes in labour productivity or in profitability (Megginson and Netter, 2001). Only a more limited set of authors explore social costs and benefits of privatization, and particularly their impact on prices and redistribution of welfare: examples are Galal et al (1994), Newbery and Pollitt (1997), La Porta and Lòpez-de-Silanes (1999), Florio (2004) and other contributions reviewed by Birdsall and Nellis (2003) .
} 
"It is possible that due to data limitations and perhaps even methodological flaws, statistical models do not accurately measure the true welfare impact of these reforms. It is also possible that public perceptions are subject to systematic biases" (Kessides,2004, p.58).

According to Kessides, empirical research should focus on the collection of comparable crosscountry micro-data on prices and consumption, in order to discover the true welfare changes following utility reforms. These detailed micro-data, however, are currently unavailable in Latin America and elsewhere (see http://www.privatizationbarometer.net/upp/respar.htm, for information on a new research project supported by the European Commission). In this paper we use a different, albeit complementary, research strategy. In fact, contrary to what is said by the first quotation above, we do observe sufficient variability in perceptions across countries and across a number of socio-economic characteristics of the respondents, and we use this fact to explore possible determinants of perceived failures.

Obviously we cannot rule out the suspect that respondents are uninformed and that they give the 'wrong answer', as suggested by the second and third quotation. However, finding recurrent patterns across countries points to the existence of substantive phenomena, difficult to capture by using more aggregate data, e.g. about tariff or expenditure changes for the average consumer. Hence, we suggest that the analysis of subjective micro-information may contribute to the redesign of empirical research on actual measurable welfare changes and of policy reforms themselves, because micro data on perceptions show where problems are actually encountered, for example in which specific social groups.

In this paper we explore social attitudes information available from Latinobarometro, an independent survey regularly performed every year on representative samples of 17 Latin American countries. A recurrently asked question is the following: "The privatization of state companies has been beneficial to the country?". The sample summary results are reported in table 1 . They show that more than half of the interviewees disagree with this claim, and the percentage has been increasing of almost 20 points over the three surveys we consider (1998, 2000 and 2002). The rising discontent with respect to privatization is certainly correlated with a change in general attitudes. In fact the country economic situation is perceived as somewhat worsened, and the confidence in the market has declined (see table 2). Nevertheless, simple inspection of the numbers seem to suggest that the change of attitudes towards privatization is more pronounced than other changes of perceptions, and we wish to test how far opposition to privatization is just a reflection of economic pessimism, or if it reflects additional concerns.

[insert tables 1 and 2 about here]

We estimate various models predicting the attitudes towards privatisation. After controlling for usual demographics (gender, age, education, working condition) and general attitudes towards related issues (see items reported in table 2), we concentrate on the correlation between attitude towards privatization and social conditions of respondents (which is subjectively and objectively measured). We show that the strongest opposition originates from middle-to-low socio-economic strata in the population, which are not necessarily less educated than richer classes. We also take into account the economic environment by adding some macroeconomic controls at country level (gdp growth, public expenditure, income inequality and illiteracy rates) as well as information about privatization characteristics (composition by sector, timing, and amount of divestiture proceeds). We consider privatization features using two datasets: one data set (FEEM Privatizationbarometer, and Securities Data Corp., see above web citation) offers information about 340 divestitures occurred in Latin American countries, over the period 1990-2001. The second one (Private Participation in Infrastructure Database, see, http://ppi.worldbank.org/) includes 923 infrastructure projects with private participation (including divestitures, concessions and other contracts) over the 
period 1984-2002. These data allow us to see the impact on attitudes of various privatization characteristics, including sector, type of contract, timing, share of utilities, etc).

Our main finding is that the highest probability of disagreement with privatization is encountered when the respondent is secondary school educated, is middle or low in terms of socio-economic conditions, the privatization has involved a high proportion of public utilities (as water and electricity), and the country suffers high inequality in the distribution of incomes. There is some evidence that concessions or other public-private contracts are less unpopular than outright divestiture, while distressed contracts contribute to raising discontent. Our results are fairly robust within each survey and for most countries individually taken. We suggest that these findings depict a broadly consistent picture of privatization discontent that points to a combination of perceived distributive concerns, privatization features, and the economic environment that should be addressed by future research and policy design.

The structure of the paper is the following. In section 2, we discuss the conceptual framework on social benefits and costs of privatization, the possible relationship between objective and subjective evidence, and our research questions, along with some background history of different national models of reform, and earlier empirical research on the welfare impact of privatization in Latin America. In section 3, we present our data sources and empirical findings. We conclude summing up our results, and their implications for further research and policy design.

\section{Social benefits and cost of privatization: theory and evidence in Latin America}

\subsection{Welfare effects of reforms}

While we test perceptions, and not verifiable welfare changes, an analytical framework is helpful to understand how in principle the various agents can be affected by public divestitures. Among others, Drèze and Stern (1990), Jones et al. (1990), Galal et al. (1994), Newbery and Pollitt (1997), and Florio (2004) offer a detailed discussion of this issue.

The social welfare change of a policy reform can be seen as the sum of the welfare changes of four individual types: consumers, taxpayers, shareholders and workers. There may be other agents involved if we consider for example the suppliers and competitors of privatized firms, or foreign investors, but the latter have usually less weight in the social welfare evaluation. Each term can be dealt with separately when we know how to estimate it from observable data.

As for aggregation, given a social welfare function, e.g. of the Bergson-Samuelson type, one needs welfare weights to evaluate the change of welfare of respectively different consumers, taxpayers etc. Alternatively we need specific weights to evaluate the marginal impact of the change in welfare of group of representative consumers, tax-payers and so on. One should be careful however with the aggregation assumptions. Applied economists would like to have all the relevant information to make the appropriate calculations, and to understand the differential impact of a policy reform on specific group of agents and to estimate shadow prices for general equilibrium effects. These data are often not easily available. Conjectures and prior beliefs unavoidably bias applied research on policy reforms. In turn, when an individual is asked whether in his or her opinion a reform was 'beneficial to the country', the interviewer elicits a sort of very crude social cost-benefit assessment by the respondent. The concerned individual will partly answer on the basis of her direct experience, partly on her ideology and external factors. We discuss below some of the factors that in principle may influence the judgment of an observer of privatization. We focus particularly on consumers because the earlier research mentioned above show that they play the key role in the welfare evaluation of policy reforms. 
Privatization $^{3}$ may have a direct impact on consumers' welfare, particularly through the divestiture of state-owned public utilities and other public services. Following privatization, consumers may experience several changes:

- in their potential access to the network of utilities or to other public services (e.g. there is network expansion because of the release of investment constraints that affected the former state owned enterprises - SOEs henceforth - or a cut of services in some less profitable regions)

- in the tariff structure (e.g. changes of access charges, fixed components of the tariff, prices per unit of service, payment method, tariff rebalancing among type of services)

- in the quality of service (e.g. number of failures in telephone calls, breaks in delivery of water or electricity)

- in the prices of substitute/complement goods (this is however less verifiable by the consumer).

Each of these dimensions poses difficult challenges for empirical research on welfare changes. In principle we would need time series of individual micro-data and of related controls. Some of these data are available to the utilities, but are not in the public domain. Other data are available by official expenditure surveys, but their country coverage is uneven in Latin America and not comparable across countries. Aggregate information on the "average" consumer is not well suited for welfare analysis and may conceal redistributive impacts. We cite below some interesting evidence of such impacts following utility reform in Latin America, but overall objective evidence is patchy.

Before moving to empirical evidence, let us consider why, in principle, the redistributive dimension of utility reform may be significant. In the aftermath of privatization, the poor (by income share or by source of income, e.g. pensioners) often suffer a risk of being net loser mainly because the abolition of cross-subsidies in the tariff structure. SOEs used implicit taxation of business users (or other high volume users) by charging higher tariffs, and the rent was then used to implicitly subsidize household users. Thus, in some countries SOEs deliberately distorted prices in such a way as to sell at prices below long run marginal costs (LRMC) to some types of users (e.g. residential users in water, telephone, transport, electricity and gas) and above LRMC to other types (particularly business users). In principle, if privatization generates the incentive for managers to devote more effort to decrease production costs, this efficiency shock may countervail the adverse redistribution impact, creating a positive-sum game (at least in absolute welfare terms). This Paretoimproving reform is, however, unlikely under sustained market power of the incumbent, or under weak regulation, and adverse welfare redistribution may appear, at least for some initial years. Moreover, under poor regulatory framework, regressive price-discrimination substitutes for the previous pattern.

Because of lack of appropriate data, some empirical research in this area risk often to miss the point when it has to assume "that all households were sold the same product at the same price", in the words of McKenzie and Mookherjee (2003, p.4). The variability of welfare changes across social groups is, however, the key issue for the distributive impact of reforms in many sectors.

In this paper we propose a complementary research strategy to the traditional welfare changes measurement. We assume here that consumers have at least some relevant information on access, quality, quantity and prices of the public services they use, before and after privatization. Hence, we assume that their attitudes on the social benefits of privatization depend at least partly upon this

\footnotetext{
3 'Privatization' is here a synonym for a wide set of reforms including divestiture of state-owned enterprises, market liberalization and re-regulation. In fact the time sequence is often the above ordering. While privatization is a generic label for several reforms, in this paper we test the differential impact on social attitudes of outright divestitures of SOEs versus other contracts involving private finance, including concessions, lease and greenfield projects.
} 
information, as upon several other factors as well. People may be uninformed about the overall welfare changes in the country, or general equilibrium effects, but we maintain that they are able to assess the relevant changes affecting their consumption expenditure. Still, agents may be wrong in gauging the exact extent of the change, but if perception errors are randomly distributed, the direction of change may be on average perceived correctly. One may of course make specific ad hoc assumptions on perception errors, e.g. assume that less educated people make more evaluation errors. We prefer to avoid such ad hoc assumptions, but we control social attitudes with education attainment, and several other individual characteristics.

Thus, it seems reasonable to conjecture that when the actual (unobserved) welfare impact of privatization is regressive, a large number of the respondents in a social attitudes survey, particularly in countries with high income inequality, will be critical of the reform, and support to privatization will decline with income or objective well-being of the respondents. ${ }^{4}$ As a consequence, a country with sizeable income inequality is more at risk of privatization discontent. The social aversion to inequality is probably not linear in inequality itself, and any reform perceived as regressive in countries where inequality is high may be unpopular (see Graham and Pettinato, 2002, for a discussion of the relationship between subjective well-being and income profiles). Particularly important is the change of inequality over time. Worsening inequality can reinforce the perception that privatization may directly contribute to this process, or that the regressive consequences of privatization, albeit transitory, may be unbearable by those in the lower income brackets, especially when they have to face tariff rebalancing.

Under this angle, we would also expect that the public support to privatization decreases when industries to be divested include a high proportion of utilities, because middle to low income consumers, accustomed to previously subsidized tariffs pay a non negligible share of their income in utilities bills. In fact, the adverse redistribution effects, or related fears thereof, are more likely for public services, while the concern for selling state-owned manufacturing business, or financial services, is probably stronger among workers in those sectors, but probably not so important for the general public.

An additional dimension of privatization discontent may be related to an excess of divestiture in short time. Under these circumstances long habits of consumers of public services are suddenly disturbed, and even if quality of services may gradually increase and their prices decreases, initial reactions to a shock may be negative from consumers.

One important research question is about the various forms of privatization. Outright divestitures may be perceived as more welfare damaging by the poor than concessions or other forms of publicprivate contracts, because the Government's role in the latter case may be seen as stronger. This perception, however, may be disturbed by news of distressed concession contracts, and frequent renegotiation (Guash, 2004).

\footnotetext{
${ }^{4}$ Under this angle survey data may be a complement (certainly not a substitute, however) to more traditional welfare analysis based on expenditure surveys or industry statistics. As mentioned at the beginning of this section, other social groups directly involved in the reforms are shareholders, workers, and taxpayers. Usually the first are winners (because of underpricing of shares at initial public offerings and residual market power of the incumbents), the second losers (because of overmanning in the SOEs), and the third are winners or losers depending on the specific fiscal choices of government (e.g. the use of privatization proceeds either to sustain public investment or current expenditures, or to redeem debt). The welfare impact of such changes will be often regressive. Thus it is crucial to assess the welfare impact on consumers, because they outnumber the other groups in population and in the representative samples of social attitude surveys. A detailed discussion goes beyond the scope of the paper; see Drèze and Stern (1990) and Florio (2004).
} 
Eventually, macroeconomic conditions may also influence these perceptions: if a country suffers macroeconomic shocks, respondents are more pessimistic on their future incomes and they may fear a privatization implying higher prices, cutting public services and/or creating the necessity to recur to costly substitutes.

The above discussion sets some research questions to be tested empirically. They boil down to two more general questions: Who are the discontents? Why they disagree that privatization has been beneficial to their country? In the next section we present some features of privatization in Latin America that justify why the region seems to be a very suitable candidate to test our conjectures on both questions.

\subsection{National variations in privatization patterns in Latin America}

The privatization process in Latin America in the '90s was part of a political and ideological trend common to most political parties from the right to the left (Murillo, 2002). This common trend showed, however, national variations: differences are related to the magnitude, velocity, depth and methodology of the privatization. This could give origin to different perceptions about privatization in each country, and we wish to exploit this variability in our research design.

Regarding the scale of the process, important disparities exist between counties. The cumulative revenues of privatization during the period 1988-1999 were higher than $8 \%$ of GDP in four countries: Bolivia (19.7\%), Peru (13.2\%), Brazil (10.9\%) and Argentina (8.6\%), whereas they did not exceed 3\% of GDP in Honduras, Ecuador, Costa Rica, Paraguay and Uruguay (Chong and López de Silanes, 2003; Lora, 2001; Lora and Panizza, 2002). The fact that Chile is not among the most intense privatizers is partially due to the fact that it started earlier than the rest of the countries. Mexico was another earlier privatizer but the revenues in this first stage were not significant (McKenzie and Mookherjee, 2003).

As regards to the sectors that have been involved in the process, $75 \%$ of the value of privatization's revenues came from utilities and infrastructure, the financial sector representing $11 \%$ and the rest came from oil, gas and manufacturing. Most of the countries privatized telecoms, electricity, gas, water and sanitation services. Privatization of railways, airlines, airports and highway were less extensive. Divestitures of financial and productive sectors were not so important because private participation was already present there. Additionally, most governments insisted on retaining one or more public banks and, except Argentina, governments opted for retaining under public control the companies connected with natural resources (such as oil, gas and copper). In contrast to Eastern Europe, divestitures in manufacturing was not important in Latin America, except for some old strategic heavy industries such as steel, aluminium and so on. ${ }^{5}$

There is a common perception of Chile as a leading case in Latin America privatization, which is based more on the characteristics and extension of the process than in its depth. In this country, the state withdrew from social security, health and education systems but, simultaneously, retained ENAMI and Codelco (the most important player in the copper sector), the monopoly of the oil sector, the fourth commercial bank, the post, the railways and the ports. Thus, the share of SOEs in the GDP after privatization reaches $9 \%$; which is higher than the average of LA countries $(5 \%$,

\footnotetext{
${ }^{5}$ Although Brazil was one of the most important privatizers in the world, it retained state participation in electricity, the financial sector and oil (Anuatti-Neto et al, 2003). Colombia, Costa Rica and Uruguay were the only countries where telecoms were not privatized (Lora, 2001; Pombo and Ramírez, 2003). In Peru, which underwent one of the most intense divesture processes measured with respect to GDP, there has not been private involvement in transport, sanitation services and an important presence in agriculture is maintained by the state.
} 
according to Fischer et al. , 2003). In contrast, Argentina did not retain the ownership of any important state company, with the exception of some national and provincial banks and some provincial companies of sanitation (Galiani et al., 2003). The cases of Mexico and Uruguay showed a very important role for the state-owned financial sector. In the former case it represented a 50\% and in the latter $90 \%$ of total revenues. For most countries, privatization in energy represented a minimum of $20 \%$, but in Mexico, Venezuela and Uruguay practically nothing was privatized in that sector (Lora, 2001). ${ }^{6}$

The strategy of privatization was also different among Latin American countries. Bolivia, Chile, México and Nicaragua privatized first the SOEs in the competitive sector (manufacturing and finance) and then, in a second phase, the utilities. Other countries like Argentina, Brazil, Colombia and Peru sold both types of companies simultaneously. In some countries (Bolivia, Argentina) the monopolistic structure of some sectors was maintained in order to maximize the revenues, even in sectors like telecoms where the technology allowed more competition.

The governments used different methodologies for selling SOEs to the private sector: total sale through open international options, public offering of shares, concession contracts, and direct transfers. The intensity in the use of each strategy differed across countries. Argentina, Chile, Mexico and Peru employed outright sales, while schemes of capitalization were used intensively in Bolivia (investors did not pay proceeds to the Treasury and committed themselves to sink capital in the companies). Concession contracts were mainly used in sanitation services, transport infrastructure and oil exploration and production, with rather unstable stories. ${ }^{7}$ There were also several attempts to 'democratize' the property, inviting small investors and workers to participate in the equity of companies. That common trend was especially intense in Argentina, Brazil, Colombia, Chile and Peru. But the most important strategy of capitalization was followed in Bolivia, where, as said, no fiscal revenues from divesture were actually cashed by the state. However, as Anuatti-Neto et al. (2003) pointed out with respect to Brazil (and easily applicable to the rest of the countries) the governments neglected the opportunity to really diffuse ownership.

Eventually, there is a particularly significant international dimension. In every country privatization implies important inflows of foreign direct investment (FDI). Foreigners participated not only with capital but also taking over company operations. In the entire region, FDI flows changed - in terms of GDP - from $0.3 \%$ in 1989 to $6.9 \%$ in 1999 . Until the late eighties, most Latin American countries posed several barriers to foreign participation in services or strategic companies and the same happened with the remission of utilities. Once these restrictions were eliminated the privatization process played a key role in the attraction of foreign capital. According to Lora (2001), the $36 \%$ of FDI was directed to privatization.

Overall, we can conclude that there is wide variation in national privatization patterns in Latin America, despite the broad common policy trend. This adds an interesting perspective to our research line. Had all Latin American countries followed an identical pattern of privatisation, potential variations in national attitudes towards privatisation would have been attributed to country specific compositional effects, without being able to identify which feature of the privatisation process may result most unpleasant to the majority of the population. On the contrary, since

\footnotetext{
${ }^{6}$ Uruguay was the only country that did not privatize electricity, oil and telecoms. In general the rest has privatized al least one of these sectors (Lora, 2001). Additionally, Uruguay is the sole country where public opinion expressed their opposition to privatization of these companies in different referendums. No other country has shown this popular participation in the privatization debate. Nicaragua is a particular case; it was the only country in LA that to some extent represents a transition from a socialist economy to a market economy.

${ }^{7}$ Guasch (2001) says that in LA in the last 15 years, $40 \%$ of the concession contracts were renegotiated just 2.2 years after.
} 
countries followed a specific pattern, we can investigate whether there are systematic effects on the popularity of privatisation reforms.

\subsection{Existing empirical research on the redistribution effects of privatization}

Our discussion in section 2.1 suggests to consider the effects of access and price changes on income distribution and poverty as possible determinants of discontent, in addition to welfare effects on workers, tax-payers, and shareholders. In order to analyse the impact of privatization in a crosscountry perspective we take advantage of several papers that cover nearly all the main countrycases or give a cross-country evaluation of Latin America ${ }^{8}$ as a whole.

Some studies suggest that privatization had positive effects on the poor through the budgetary and fiscal indirect effects, since in countries like Bolivia and Argentina privatized companies are now the main taxpayers (Chong and López de Silanes, 2003; Harris, 2003). Nellis (2003) argues that the budgetary effects are more important than sales proceeds and the regressive impact of underpricing. McKenzie and Mookherjee (2003) remark the positive impact of fiscal revenues on stabilization policies. This helped disinflation that may benefit the relatively poorest people. Additionally, these revenues could have been used by the state to help the poor to compensate the negative effects of privatizations. Chong and López de Silanes (2003) assert that Argentina, Bolivia, Mexico and Peru are good examples where SOEs generated such big losses that privatization revenues and taxreceipts were probably large enough to offset the social costs of job losses. On this line, see also Benitez, Chisari and Estache (2003) who use a general equilibrium model to show that privatization had progressive welfare effects.

Having said this, it is still likely that microeconomic impacts of privatization are more direct and dominant in welfare terms, or at least in perceptions. It is beyond dispute, for example, that profitability increased everywhere after divestiture: more than $40 \%$ in Peru, Mexico and Argentina, but less than $10 \%$ in Brazil, Chile and Colombia (BID, 2002). The main reason behind these improvements in profitability was operating efficiency gains (Chong and López de Silanes, 2003). There were, however, social costs associated with such changes. In fact, downsizing was a key ingredient of companies restructuring (McKenzie and Mookherjee, 2003). Except for Chile, the employment in SOEs was reduced at sizeable rates: $55 \%$ in Peru, $40 \%$ in Argentina, $36 \%$ in México, 23\% in Colombia and 10\% in Brazil, but in the long term there was a partial recovery of direct and indirect employment in privatized sector (BID, 2002). However, the reduction in staff was not big enough to become recognisable in the official unemployment rate or to explain the generalized deterioration of labour market indicators in most of the LA countries (Chong and López de Silanes, 2003). The conclusions from most of these papers are similar and in accordance with worldwide evidence (Megginson and Netter, 2001; Harris, 2003): privatization had positive impact regarding productivity, profitability, and fiscal revenues, but had some social costs in terms of employment.

\footnotetext{
${ }^{8}$ McKenzie and Mookherjee (2002) present the main results of Ennis y Pinto (2002) for Argentina, Barja, McKenzie and Urquiola (2002) for Bolivia, López Calva and Rosellón (2002) for México, and Freije and Rivas (2002) for Nicaragua. More recent papers are reviewed in Chong and López de Silanes (2003). They present seven studies for different countries of Latin America (Argentina (Galiani et al, 2003), Bolivia (Garrón et al, 2003), Brazil (Anuattí-Neto et al, 2003), Chile (Fischer et al, 2003), Colombia (Pombo y Ramírez, 2003), Mexico (La Porta and López de Silanes, 1999) and Peru (Torero, 2002)). The advantage of these studies is more comprehensive data sets. Harris (2003) and Megginson and Netter (2001) present worldwide evidence, including Latin America. Nellis et al (2004), is another general study that specifically tries to understand the gap among public perception and economic reality as described by empiric works. Other contributions are Chisari, Estache and Romero (1995), Estache, Gomez-Lobo and Leipziger (2000), Estache (2003), papers from WIDER and FLACSO (Azpiazu and Schorr, 2003).
} 
When we focus on current research on direct welfare changes for consumers, scholars' opinions are more divided and evidence more scattered. As mentioned in sub-section 2.1, the distributive impact of privatization depends on three main factors. ${ }^{9}$ The first one is the change in the access to services; it is related to the expansion of networks and the introduction of technological innovations that facilitate access, as in the case of telecoms. The second factor is the change in affordability, which is related to the tariffs rebalancing, the temporal evolution of prices and the way this affects the preexisting and new customers. Change in quality is important but difficult to measure, and we are not aware of comparable empirical research in this area across Latin American countries.

Regarding the question of access to public services, namely electricity, telephone and water, McKenzie and Mookherje (2003) mantain that private participation contributed to an expansion of these services. Increased investment in the network could have contributed more intensively to the access of the poor to electricity. Their data source, however, do not allow for direct information on connections, in fact what they observe is increased expenditure or use: this do not allow for changes from illegal to legal connections. In the case of telephone services, given the lower earlier coverage, the network expansion benefited mainly the upper and middle classes. Ugaz and Price (2003) confirm this tendency of relative improvement of poor customer's access. However, the deficit of connections continues to be high especially for sanitation services in urban areas and for all services in rural areas. According to Chisari, et al. (2001) the Latin America experience shows that the poor are the last in receiving the benefits of higher access generated by privatizations. For instance, the rural poor are normally omitted from the reform because of the low profitability of these areas. Rural regions in Bolivia, where most people are poor, are an example of this contrast with urban areas (Barja and Urquiola, 2001).

Evidence about the impact of privatization on utilities tariffs is mixed. It depends, among other things, on the sector and on the country, the technological progress in the industry, how far prices were below cost-covering levels previous to privatization and, eventually, the regulatory framework. An example of critical assessment for the Argentinean case is the work of Azpiazu and Schorr (2003). These authors criticize the normative framework in which privatized companies operated. They consider the high level of prices at the beginning of private operations, the "regulatory delay" to translate the higher productivity gains into lower prices, the indexation of the domestic tariffs according to foreign inflation and the systematic practice of renegotiating contracts promoted by companies and validated by the government. They argue that the way in which the privatization process took place tended to create and preserve non-competitive markets.

According to McKenzie and Mookherje (2003) the evolution of tariffs after privatization did not have a clear trend. They examine ten countries in Latin America and find five cases where they increase and five where they fall. Particularly, these country studies seem very sensitive to the fact that some government increased tariff before privatization. On the other hand, Ugaz (2002) remarks that privatization implied new tariff structures which was more cost-reflective. For the three countries she considers, she finds the same pattern of rebalancing: an increase in fixed charges and a decrease in variable unit prices. The magnitude of this relative change in tariff composition depends on both the previous degree of distortion and cross subsidies under public management. As a result of this tariff rebalancing, the pre-existing low-income customers and especially the poor were penalized with substantive losses in the consumer's surplus. People in the bottom deciles of the income distribution suffer more intensively in absolute and relative (to their income) terms (Ugaz and Price, 2003).

\footnotetext{
${ }^{9}$ The fourth factor we mentioned at the beginning of this section is the indirect impact on prices of other industries. This may be important but difficult to study and consumers are unlikely to have information on such general equilibrium effects. See Chisari, Estache and Romero (1995) for an earlier attempt to consider this impacts, and more recently Benitez, Chisari and Estache (2003).
} 
Residential customers were more exposed to tariff increases than the commercial and industrial ones, particularly in countries where there were cross subsidies. In several cases, fixed charges represent a big portion with respect to the variable tariff component, such that the affordability problem for low users is very sensitive to connection charges (Chisari et al., 2001). In Peru, Chile and Argentina there was an increase in local calls tariffs that affected poor people more (Paredes, 2001; Torero and Pascó-Font, 2001). In Bolivia, the rebalancing in electricity was harmful for lowincome household (Barja and Urquiola (2001). Anuatti-Netto et al (2003) show the same pattern for the Brazilian case in electricity and telecom. They remark the increase in minimum monthly fees for access to a line as a key redistributive issue.

A paper that supports our conjecture about the occurrence of regressive redistribution is Delfino and Casarin (2003), who analyze the change in the consumer surplus in Argentina. The authors found that low-income households were particularly damaged because of the increases in fixed charges in the utilities. They consider the distributional impact associated with the privatization of telecoms, gas, water and sewerage in the Gran Buenos Aires area, comprising one third of the country's population. The paper uses an official household expenditures survey data-set, with monthly data collected around 1996-1997 for 5000 households. The data-set includes information on income and expenditures, demographic and personal characteristics, availability and use of utility networks. Based on this information, they calculate a simple Marshallian surplus change, following Waddams Price and Hancock (1998), the ratio of these welfare changes to income by quintile, and sensitivity to various price elasticity values. We report some of their results for the most plausible elasticity assumptions in Table 3. The table shows that for all four utilities together, the yearly surplus change was of 112 USD (at constant prices) for the 5th income quintile of consumers, but it was a net loss of 51 USD for the poorest quintile. According to our own recalculation, this is equivalent to a gain of 0,33 percent on annual income for the rich and a quite substantial loss of 1,3 per cent for the poor. ${ }^{10}$ As the table shows, the distribution of welfare changes is strictly regressive in money terms. Relative to income, the impact is even more significant. We suspect that, in terms of perceptions, while the net benefit for the two upper quintiles is probably negligible, and for the middle income group the impact is neutral (but for gas and water there are net losses), the negative impact of tariff changes cannot go unnoticed by the two bottom quintiles. For these relatively poor consumers, expenditure in utilities claims a high proportion of income, hence any price change is important. This not negligible reshuffle of welfare perhaps helps to explain why we find that the highest disagreement with privatization in our data is in Argentina.

\section{[insert table 3 about here]}

In a general overview Ugaz and Waddams Price (2003) confirm that in LA utilities' tariffs increased very frequently and this affected the poor more, even if increased access data may suggest a more positive evaluation. The evidence, according to these authors, raises the question of the distributive impact of privatization on utilities and the effectiveness of regulation to protect poor consumers from monopoly power in most countries in Latin America. In fact, Kessides (2004) remarks that while overall privatization and liberalization have been beneficial to consumers in developing countries, policy makers and regulators too often did not find a balanced price structure in terms of the trade off between efficiency and equity objectives.

To sum-up: first, the theoretical literature on social cost-benefit analysis of privatization does not reject the possibility of regressive welfare changes, not addressed by regulation or other policies; second, country variations in privatization policies are sizeable in Latin America, and this fact can be used to test subjective perceptions; third, while traditional empirical research, based on objective

\footnotetext{
${ }^{10}$ Delfino and Casarin report an even higher loss, in the order of $2 \%$, in their comment to these data.
} 
data, supports the view of a positive impact of privatization on productivity, profitability, fiscal balance and perhaps on general equilibrium effects, the evidence on the impact on workers and consumers is more mixed. Given the evidence of large downsizing following divestitures, and of regressive tariff rebalancing in some countries and sectors, Latin America seems to offer a suitable laboratory to test whether income and objective well being influences social attitudes toward privatization, controlling for other individual characteristics; and to use country variability of privatization characteristics, controlling for macroeconomic conditions, to explore possible additional determinants of discontent.

\section{Empirical analysis}

\subsection{Data}

Our social attitude data derive from LATINOBAROMETRO (www.latinobarometro.org) an annual independent survey carried out in several Latin American countries. The survey started in 8 countries in the region in 1995 and extended to 17 countries in 1996. The waves we use were conducted in 1998 (November and December, except El Salvador, Honduras and Nicaragua, which were surveyed in March 1998), 2000 (between January and March) and 2002 (during April and May). ${ }^{11}$ Sample sizes are approximately one thousand per country. ${ }^{12}$ In addition to usual demographic information (gender, age, educational attainment, occupational status, ownership of durables), the surveys contain some recurrent questions about current economic situation, scope for pro-market reforms and opinion about privatisation. We exploit some of these questions, in order to take into account the general attitudes of the interviewees. For example, we make use a question on the current situation of the country ("In general, how would you describe the present economic situation of the country? Would you say that it is very good, good, about average, bad, or very bad?") in order to control for the degree of optimism/pessimism of the surveyed individual. ${ }^{13} \mathrm{We}$ also (at least partially) control for potential ideological bias by using the expressed opinion on general economic issues ("The market economy is best for the country ?").

Our focus is the opinion of interviewees about the consequences of privatisation. In all three surveys there was the question whether "The privatization of state companies has been beneficial to the country?". ${ }^{14}$ According to the wording of the question, the interviewees were not asked whether the privatization was beneficial to them, but to the collectivity. Using the economists' jargon, one could rephrase the question posed by the survey as "did the privatization raise the social welfare ?". Even supposing that a man in the street may understand such a question, we could not expect a unanimous answer the question, because individuals not necessarily share the same value judgements about social welfare and the same information.

This may explain why there is sizeable dispersion in public opinion with respect to the potential benefits of privatization, as reported in table 1. On average, two third of the population sample expressed against a beneficial role of privatization, and this opinion may be affected by several respondent's characteristics (like age, gender, education, income, wealth, family composition). If this were the case, since these features are approximately similar across countries, we would have

\footnotetext{
${ }^{11}$ We could not exploit more recent waves, since 2003 survey contains a standard question about privatisation, but does not report additional questions about market scope and role of the state, while 2004 survey does not ask a generic question about privatisation, but asks for an opinion about specific privatisations (water and electricity).

${ }^{12}$ More precisely: 17839 observations in 1996, 18038 in 1998 and 18522 in 2000.

${ }^{13}$ When available (in 2000 and 2002 only) we also consider the subjective evaluation of individual situation in terms of happiness ("Generally speaking, would you say you are very happy, quite happy, not very happy, not at all happy?").

${ }^{14}$ Panizza U. and M.Yañez 2003 analyses a larger data set from Latinbarometro including more survey years, but excluding the survey conducted in 2002. They follow a different line of research, since they are interested in investigating whether the attitude against privatisation could be accounted for a left-bias orientation of the respondents, and/or an increase in political activism. Our results are consistent with theirs in finding that favourable economic conditions reduce political opposition to privatisation.
} 
expected an analogous distribution when considering the attitude within each country, if they explain most of the social attitudes.

On the contrary, in table 4 we notice that there are wide variations across countries and years: the strong disagreement scores as high as 45.1\% in Argentina in 2002 and as low as 2.73 in Guatemala in 1998, as well as the support hits the highest in Venezuela in $2000(22.8 \%)$ and its lowest again in Argentina in $2002(1.7 \%)$. This implies that we can exploit cross-country and cross-year variations in respondents' opinions: if anything systematic survives once we control for sources of potential variations, we believe to have found robust factors. ${ }^{15}$

\section{[insert table 4 about here]}

Thus, the survey opinion about privatization is the outcome of both individual characteristics and country experiences. We can control for the former using available information from the survey, while for the latter we resort to aggregate evidence on the actual experience of privatization. By so doing, we gain insight on two issues:

i) identify the population subgroup that is more fiercely opposing the privatization of state enterprise. As long as their judgment is dependent on their social position, these people are more likely to be the potential damaged from this experience.

ii) classify the country privatization experiences according to their impact on social opinion, controlling for macroeconomic conditions, and ascertaining which are the features that create social discontent.

As far as individual information available, we possess information about gender, age, marital status, educational attainment, employment condition, ownership of durables goods (colour TV, refrigerator, housing, computer, washing machine, telephone, car, second home, drinking water, hot water, sewage system) and self-assessed socio-economic status. Most of the information is summarized in this variable, as it can be grasped by table 5: a "very bad" socio-economic condition is typically associated with lack of proper housing (in the $42.7 \%$ of cases), drinking water at home (37.0\% of cases), not to speak of car $(89.0 \%)$ or computer $(95.2 \%)$. At the opposite extreme, a "very good" condition is associated with ownership of colour TV set $(97.5 \%)$, refrigerator $(95.3 \%)$, drinking water (95.6\%). Table A.3 in the Appendix analyses the correlation between the selfassessed socio-economic status and its potential determinants. Rather surprisingly, the perception of deprivation is highest in the absence of electric/electronic appliances (TV, refrigerator, telephone, and, with the highest coefficient, on computers!) and car; more basic services related to sanitation (drinking water, sewage) score lower in the ranking. Even when we control for education of the interviewees (fifth to eighth columns) these perceptions are retained. The socio-economic status improves with educational attainment, whereas it declines for unemployed and salaried.

[insert table 5 about here]

\subsection{Determinants of attitudes, or: what type of people are most dissatisfied with privatization?}

We now move to the analysis of individual determinants of the attitude towards privatization. We have coded our dependent variable (ATTITUDE) by assigning zero value to uncertain respondents, negative values to those expressing disagreement towards privatization ( -2 'strongly disagree', -1

\footnotetext{
15 Notice that the percentage of interviewees without a specific opinion varies significantly across countries, indicating that the issue of privatization is differently perceived. In table A.1 in the Appendix we report the estimates of the probability of non-reporting an opinion in the survey. We find that women, people without formal education and in a bad or very bad self-assessed socio-economic condition, are most likely to not report an opinion. Notice the statistical insignificance of variables reporting difficulties in understanding the question, or the interviewee lamenting dislike for economics.
} 
'somewhat disagree'), and symmetric positive values for the supporters of privatization. Table 6 presents some descriptive statistics of our variable set, whereas in table A.4 in the Appendix the same variables are presented by country. Descriptive statistics indicate that half of the sample is made of women, with average age below 40 (youngest samples in Nicaragua, Guatemala and Peru). The respondents are head of family in half of cases. It is interesting to note that a large fraction of the population has enrolled but not completed different levels of educational attainment. Higher levels of education are recorded in Bolivia, Chile, Panama and Peru. The socio-economic level indicates the worst situations in Guatemala, Mexico and Peru. However there are different trends in the perception of socio-economic deprivation: while there is a clear deterioration in Bolivia, Peru and Nicaragua, a trend reversal is observed in Honduras and Mexico. By taking into account missing observations on some variables (mainly on employment conditions and/or marital status), we have 51.635 observations available.

\section{[insert table 6 about here]}

Table 7 reports our main findings, before using any objective control, and using two alternative estimators, least square (columns 1-3) and ordered probit (columns 4-6) under alternative specifications. Results are substantially identical in terms of sign and significance, and therefore we will comment ordered probit only.

Among demographic characteristics, gender is never significant and age is the most significant, exhibiting a U-shaped pattern, with a computed age of minimum support equal to 50 (corresponding to the $77^{\text {th }}$ percentile in age distribution). Similar pattern are observed for the years of education, with a minimum support for 7 years of education. ${ }^{16}$ However, given the institutional differences across country, we prefer a specification of the educational attainment using dummies (as done in columns 2-3-5-6). In this case a negative opinion about privatisation is most likely to come from middle-low level of educational attainment (highest among respondents with "uncompleted secondary education", corresponding to a median value of 9 years of education). ${ }^{17}$ When looking at socio-economic condition, and having in mind that the excluded case is represented by respondents in "very good conditions", we notice that support declines with the worsening of the condition, but in a non-linear way, since those expressing against a beneficial effect of privatization are those in a "bad" economic condition, while those in a "very bad" condition seem somewhat less affected. Employment status comes out statistically insignificant in most cases, even when taking into account the distinction between salaried in private and/or in public firms; only self-employed and housewives seem to be more supportive of privatization. Similarly, marital status is not particularly significant, except the case of single member families. In all regressions, we maintained as controls country and year fixed effect, city size (positive contribution of living in the capital) and month of interview. We also control for whether the interviewer noticed some dislike of the respondent with respect to economic questions, or whether the respondent lamented problems in understanding, without finding any significant effect.

In order to control for individual heterogeneity, in the final column we have also inserted the answer provided on alternative questions: the more optimistic is the assessment of the country situation ("In general, how would you describe the present economic situation of the country? Would you say that it is very good, good, about average, bad, or very bad?"), the more encouraging

16 Panizza U. and M.Yañez 2003 claim that “...wealth is only weakly correlated with support for economic integration and education is weakly correlated with support for privatization and the free market in general". However, despite they are using a dichotomous dependent variable and different survey years, even in their coefficient it is possible to recognise a U-shaped relationship between education and support to privatisation (table 4, column 3 in their paper).

${ }^{17}$ It is interesting to note that under the OLS specification, the strongest opposition is associated with "university completed". An F-test for the identity of the coefficients of different educational attainment is rejected at $99 \%$. 
is the judgment about the effect of privatisation. Similarly, the opinions of the respondents are also correlated with their appraisal of market virtues ("The market economy is best for the country"): people believing that market economy is beneficial to the country are also convinced that privatization has been beneficial to their country, and vice versa. While these results are rather unsurprising, they indicate coherence in opinions of interviewees. In addition, they control for ideological bias of the respondents. If most of the opposition to privatization came from ideology and not from socio-economic status (and variations over time and/or across countries were the mere reflections of exogenous factors), then when controlling for other proxies for ideology, the correlation with socio-economic conditions should vanish. ${ }^{18}$ This does not occur in our results: other things being constant (age, gender, educational attainment, occupational status, and ideology), respondents in bad economic conditions express their strongest discontent to the economic consequences of privatization.

\section{[insert table 7 about here]}

We have explored the interaction between educational attainment and socio-economic level, finding that all educational levels report a peak in dissatisfaction ("uncompleted tertiary education" for those in "very bad" or "bad" socio-economic condition, "completed primary" for those in "average" conditions, and "uncompleted secondary" for those in "good" and "very good" socio-economic conditions - all coefficients are statistically significant). In figure 1 we show the estimated impact of the interaction dummies (relative to the case of an illiterate in very good conditions, the excluded case): it can be seen that those who claim that privatization of state enterprises have not been beneficial to the country are sufficiently educated individuals, and their dissatisfaction increases with the decline of their (perceived) socio-economic condition. While in the case of illiterate persons we could always think of wrong perception, this conjecture is weakened when considering people who have enrolled secondary education or even university.

[insert figure 1 about here]

\subsection{The role of privatization features, or: Why some respondents are more dissatisfied than others?}

In previous section we have identified potential opponents to privatisation, but we are still far away from explaining their dissatisfaction. The combined analysis of socio-economic status and educational attainment suggests that we have to look among the shrinking Latin-American middleto-low class, who may have suffered more than other social strata for the price change induced by privatization (see for example the population shares by country and years reported in table A.2).

Survey data do not provide obviously direct answers about the reasons for dissatisfaction, and therefore we need to resort to indirect evidence. Among potential reasons for dissatisfaction that we have discussed in section 2, we may consider at least three aspects:

i) respondents as workers are dissatisfied because the increased exposition to the risk of unemployment, due to the increased competition in the product and service market;

ii) respondents as consumers are dissatisfied because the increased price of services provided by privatized enterprises has reduced their command in the market;

\footnotetext{
${ }^{18}$ In table A.5 in the Appendix we provide some further robustness checks. In addition to estimating OLS and ordered probit model year by year, we also add additional answers available on specific years: "The State should leave economic activity to the private sector" (available in 1998 and 2002) and "Generally speaking, would you say you are very happy, quite happy, not very happy, not at all happy?" (available in 2000 and 2002). In all cases, while the effect of educational attainments attenuate, the correlation with socio-economic conditions remains significant, with the strongest effect associated with the "Bad" outcome.
} 
iii) respondents as citizens are dissatisfied because they (rightly or wrongly) believe that privatisation has reduced country competitiveness and/or has increased social inequality.

With respect to point $i$ ), we have already alluded to the fact that employment condition is weakly correlated with opposition to privatisation. In particular we would have expected public employees to be more exposed to the risk of redundancies, and therefore to express greater discontent, but we do not find any statistically significant effect. In addition, also unemployed could express some worry about the negative spill-over on their employability chances, but we do not find statistically significant effects (see the coefficients associated to employment status in table 7 and table A.4).

Similarly, point iii) is partially accounted for, when we notice that the opposition is stronger among those who believe that their countries are in a "bad" or "very bad" condition. The very same people also consider that market solutions are detrimental to the country, and that the state should take responsibility of (part of) the productive sector (see again the coefficients associated to different answers on questions about beliefs in table 7 and especially table A.4). There are therefore people with different worldviews in the sample, and part of the opposition may derive from the presence of "anti-market" ideology, which is widespread in Latin America. However, by controlling for country and year fixed effects, we are implicitly taking into account any systematic effects that are out of control of individual respondents (as it is the case for ideology, fashions and religious faiths, which can be systematically different across countries, and can also fluctuates over years).

This obviously does not solve the issue whether the respondents are using a right or a wrong model of the reality in producing their opinion about the consequences of privatisation. We believe that it is impossible to provide a definite answer to this question, especially because the "true" model could be state-dependent (and therefore a rich and a poor person could be both right in expressing opposite opinion about privatisation, without being proved false when measuring their welfare changes). But we are more interested in whether the discontent can be manipulated by the policy maker, which corresponds to the question whether these opinions exhibit any systematic component, or whether they are idiosyncratic in the population (the truth probably lying in between these two extremes). On one hand, following a materialistic line of reasoning, one could be tempted to accept the idea that political opinions are the mere reflection of class position: in such a case socio-economic conditions and beliefs would be (perfectly) collinear, and one could be in trouble in identifying significant correlations. On the other hand, if beliefs were randomly distributed in the population, then controlling for opinions on related issues plays the role of proxy for unobservable components. Under the former extreme interpretation, discontent increases as long as the income distribution worsens, while in the latter extreme interpretation discontent should remain approximately constant across countries and/or years. We believe to have been able to prove in the previous section that, given the joint statistical significance of socio-economic conditions and respondents' opinions, part of the increased opposition arise from the perceived worsening of the economic condition of specific groups of the population, independently of their ideological orientation.

We are now to consider case $i$ ), where the respondent may oppose privatisation because of its impact on consumption opportunities. We will explore this aspect in the remaining of this section. Let us begin with exploiting information available in the data-set about the ownership of durables commodities, which implicitly tells us something about consumption styles. We have grouped the commodities in accordance of the type of services they provide: proper sheltering for BASIC goods (items are housing, drinking water, hot water and sewage), easier housekeeping for ELECTRIC appliances (colour TV set, refrigerator, washing machine and telephone) and showing off for LUXURY goods (computer, car and second home). Given the nature of the original question, we have coded the variables as the absence of one or more item within each group, thus identifying the 
extent of deprivation with respect to potential consumption styles. Overall, only a happy few 3.3\% of the sample records a simultaneously zero value on all three groups of durable deprivations.

\section{[insert table 8 about here]}

If we interact these measures of deprivation with grouped educational attainments and re-estimate a model analogous to those reported in table 7, we obtain the picture reported in figure 2: the heaviest judgment comes from either people who need basic durables (like water or housing) or lack of either car, computer or holiday house. Thus we infer that there is an element of real need and contemporaneously an element of social envy that underlie the judgment about privatization. This matches with the estimates shown in figure 1: respondents in very bad conditions (i.e. lacking of basic durables) with university education probably suffer more deeply from deprivation, since they do not achieve a social role associated with their level of education. They have been unable to take advantage of potential benefits from privatization, since they do not have electric appliances, they do not travel and they cannot afford a telephone bill. Since privatization did not offer an improved economic prospect, they have a negative opinion about it. On the other side, there are a group that we would label as "middle class", who enjoy an average socio-economic condition, even if they still do not have access to luxury goods like a car, a computer or even a second house. They probably took advantage of different prices brought in by privatization, but they could not participate to the capital gain associated with most privatization. In their perception, privatization could be harmful to the country because instead of redistributing wealth to the rest of the country, retained the control in the hands of the "happy few".

[insert figure 2 about here]

This is the picture that emerges using information available at individual level. However people in different countries hold different experiences in terms of privatization, as we have discussed in section 2. In individual data this is partially taken into account by country/year fixed effect, which nonetheless are left unexplained. Suppose for example that one country (say Argentina) experienced prolonged privatisation, which involved from the very beginning public utilities, while another country (say Bolivia) followed a different strategy, by privatising natural resources at the beginning of the sample period, and then slowing down the process. If the first strategy creates more (perceived) discontent in the population, this should reflect in the econometrics by finding a stronger negative country fixed effect for the first country than for the second one. ${ }^{19}$ If we possess information related to country specific experiences of privatisation, we can investigate whether these specific features may have any impact on the average attitude of the local population (keeping constant other characteristics of the population by using adequate controls). ${ }^{20}$ For this reason we have resorted to existing data on privatization features.

The data on country-specific experiences of privatization come from two different data-sets. One data set exploits information about nearly 340 events of privatisation occurred in Latin American

\footnotetext{
${ }^{19}$ Using the specification proposed in last column of table 6 , the Argentina fixed effects are $0.25^{* *},-0.988^{* * *}$ and $0.909 * * *$ (respectively for 1998,2000 and 2002), while the corresponding coefficient for Bolivia are 0.649***, $0.576 * * *$ and $-0.322 * * *$.

${ }^{20}$ From an econometric point of view we face two alternatives: either we follow a two stage procedure (that is, we obtain estimate of country/year fixed effects from the model of table 7 - first stage - and then we regress these fixed effect on country/year specific information about privatisation), or we replace country/year fixed effect with information about privatisation in individual data analysis. Since aggregate data regressions reduce measurement errors (i.e. individual heterogeneity in opinions), but induce an upward bias in the estimated coefficients, we have preferred the second alternative.
} 
countries, obtained from FEEM and Securities Data Corporations data over the period 1990-2001. ${ }^{21}$ The second includes 923 investment projects over the period 1984-2002 collected by the World Bank. $^{22}$

From the former data-set we were able to look at the dynamics of privatization: number of events, initial and final year, duration (in months), frequency (obtained as result of number of events/duration). We also computed the economic significance of privatization (proxied by the across year average of the ratio between total proceedings from privatisation and gross domestic product) as well as the share of proceedings obtained from privazising public utilities (electricity, gas, water and sanitation) ${ }^{23}$ in total privatization proceedings (here again taking the averages across years). From the PPI World Bank data-set we obtain information about the nature of the privatization process in the broader meaning of private participation in the provision of public services (whether through contracts - concessions, management and lease contracts, greenfield projects - or through divestitures), the financial involvement of the private sector (whether limited to purchase of government assets or involving additional private investment in new facilities) and whether the project is operational or distressed. Given our focus on population attitudes, we restricted our data to projects involving utilities (Energy, Transport, Telecom, Water and Sewerage).

Using these variables, we can test whether effectively the hostility towards privatization is heavier in countries where people perceived it from basic items like electricity or water supplies. In addition we also add country macroeconomic controls: the growth rate of gross domestic product experienced by the country in the years preceding the surveys, a measure of the role of government in the economy (proxied by the general government final consumption expenditure as percentage of the GDP), a measure of income inequality (the Gini index on income distribution), a measure of deprivation (the illiteracy rate in the adult population, which typically correlates with other measures like the child mortality rate). ${ }^{24}$ Table 9 reports evidence on these variables for countries and three sub periods preceding the surveys (1990-97, 1998-99 and 2000-1). Graphical inspection of these data suggests for example that the adversarial attitude toward privatisation declines with the increase in the growth rate of GDP. ${ }^{25}$ This is perhaps indicative of potential misinterpretation of the data in the absence of proper individual controls. Growth may reduce opposition towards privatization simply because of compositional effects (the population gets richer, and we know from previous results that dissatisfaction decline with improvement in the socio-economic status), or because it is perceived as one of the outcome of privatisation (which can be controlled by including individual opinion about the country situation), or just because it represents a confounding factor for the public opinion. As long as we are able to control for individual determinants (educational attainment - correlated with the ability of comprehension of the reality, family socio-economic status, understanding of the situation, degree of optimism), the (average) opinion expressed by the population should represent a "pure" judgment of the privatization experience, which can also be correlated with country specific features. Table 10 reports information from the PPI data-set. We have computed four ratios, which are informative of the

\footnotetext{
${ }^{21}$ This data set draws from Fondazione ENI Enrico Mattei elaborations on Securities Data Corporations data, kindly made available to us by Bernardo Bortolotti (FEEM and University of Turin). Unfortunately, there were no data with respect to Nicaragua and Costa-Rica, and therefore we are forced to leave these countries out of the sample henceforth.

${ }^{22}$ Private Participation in Infrastructure Database, The World Bank Group, contains additional information on other countries, and a greater detail in terms of years and of sectors. We have aggregated the data in three waves, four sectors, and in the countries we are interested in.

${ }^{23}$ Defined by SIC codes 4911-4922-4923-4924-4941-4959.

${ }^{24}$ All these control variables are obtained from the World Tables, published by the World Bank.

${ }^{25}$ Similar effects have been noticed in Panizza U. and M.Yañez 2003, where they use the output gap as cyclical indicator.
} 
nature of the privatization process. Either using the number of episodes or the funds involved, we have considered:

- the share of privatization through divestiture (which was high in the initial years, and then declined to zero, because of the increasing role of other private initiatives, such as concessions),

- the share of projects which resulted problematic (e.g. concessions cancelled: a limited overall fraction, below $10 \%$, but probably very damaging in terms of reputation of the policy)

- the share of the purchase of governmental assets over the total private investment in infrastructure

- the share in utilities privatization due to water and to electricity (approximately one fourth in each case).

[insert tables 9 and 10 about here]

We present ordered probit estimates, weighed on sample weights and clustered errors by country in tables 11 and 12, making use subsequently of the first or the second dataset on privatization features respectively. The first column of table 11 replicates our previous results, corresponding to the final column of table 6 with the exclusion of two countries (Costa Rica and Nicaragua - observations decline from 50.242 to 44.808). Opposition to privatization is non-linearly related with educational attainment and with socio-economic status, peaking for individual with "uncompleted secondary education" and "bad" socio-economic status. In the second column of table 11 we introduce macroeconomic controls, recording greater opposition in countries where the public sector is larger (as proxied by the share of public expenditure on GDP). The third column introduces information about the features of the privatization process: (the probability of) support to privatisation declines whenever privatisation episodes are more recent (as captured by the ending date) and tend to span over a longer time interval (as captured by the duration measure).

When we combine the elements of second and third column in fourth column and we add some interactions, we obtain additional insights. While the share of privatization covering public utilities was statistically insignificant if considered alone, it becomes significant if interacted with a measure of income inequality. Since the sample average of the Gini index on income inequality is approximately $1 / 2$, this implies that privatisation of public utilities gain support in relatively egalitarian countries ${ }^{26}$, while it raises discontent whenever the social situation is plagued by strong disparities. Notice that now opposition tend to be stronger whenever the size of the privatization increases (as proxied by the incidence of the proceeds of privatization over the GDP). When considering additional interaction between individual characteristics (the socio-economic status and the proposed measures of deprivation), we find that privatization of public utilities is associated with dissatisfaction whenever individual deprivation (especially in "luxury" commodities) is higher. The three final columns re-estimate the final model by yearly sub samples.

Analogous structure is maintained in table 12, where the Private Participation in Infrastructure Database is used to characterise privatization in a broader meaning, allowing us to discriminate between divestitures and other contracts. The first two columns just replicate the first two columns of table 11 for ease of comparison. When we introduce privatization features in third column, we observe that support to privatization tends to be lower when the involvement of the private finance is more limited, either because the government retains control (and therefore the share of divestiture is lower) or because the private sector limits its participation to the acquisition of government assets. ${ }^{27}$ However these effects are average effects, that need some interpretation. When we look at each single wave we notice that the effect of divestiture reversed sign in the 1998 and 2000 surveys (remember that the index was constructed by considering privatization events over the 1984-1998

\footnotetext{
${ }^{26}$ Namely countries with a Gini index below 0.56 (obtained from 2.04/3.59).

${ }^{27}$ Similar results are obtained when considering the number of cases instead of funds invested. Available from the authors.
} 
interval). It is also interesting to notice that the share of problematic privatization is not statistically significant on average, but has a growing and negative sign when considering yearly estimates. It seems as if the public opinion had learnt to distinguish between different types of privatization. Initially respondents somewhat preferred concessions to divestitures, probably because they believed (rightly or wrongly) that the government would have maintained some control. With time passing on, the emergence of some cases of failed privatization, the end of public asset selling (as witnessed by the decline of the coefficient on the corresponding variable), there have been a reversal of attitude, with greater favour to private initiative than divestitures. When we look at the effect of composition of utility privatization (fourth column of table 12), we notice that discontent is increasing with the share of water and sewerage privatized services, and this effect is stronger the higher is income inequality. This is reinforced at individual level, since we show that privatization of water services induces more fierce opposition among those suffering deprivation of basic items (among which water and sewage at home). Similarly, privatization of electricity raises discontent among those deprived of electric appliances.

Overall our results can be summarised as follows. The bulk of the opposition to privatization derives from middle-to-low social strata, with sufficient access to information, given their level of education ( 9 years of schooling on average). This result is robust against individual heterogeneity in perception and/or ideology, and survives even when controlling for country differences in their experience with privatisation. ${ }^{28}$ We also find evidence of short-sightedness in the population: the opposition is higher when privatization ended more recently and/or lasted more months and/or was less frequent. This seems consistent with the idea of fading memory in the public opinion. Evidence of persistent attitudes can explain the negative correlation with public expenditure: populations who were accustomed to widespread intervention of the state in the economy are more reactive to the process of privatizing SOEs. We also find evidence of changing attitude in the public opinion, which seems gradually supporting the private finance initiatives. Finally, privatization of public utilities has a negative effect, depending on the pre-existing social situation. It is reasonable to assume that high inequality countries have a larger mass of pre-existing discontent. In this framework, privatization of public utilities may exacerbate social disparities, and contributes to dissatisfaction with privatization. The existence of basic deprivation and/or some sort of social envy phenomena (as witnessed by the correlation with deprivation in durable commodities) reinforces this interpretation.

[insert tables 11 and 12 about here]

\section{Concluding remarks}

This paper has offered new evidence on privatization discontent in Latin America. Since privatization is basically a change of ownership from taxpayers to private shareholders, it redistributes well-being among taxpayers, consumers, shareholders and workers. As such, it has to be considered a highly socially sensitive policy, to be carefully managed by the regulatory framework. Given the absence of suitable objective data at cross-country level, we turn to the assessment of individual agents. They offer, in a crude and perhaps biased way, the perceived

\footnotetext{
${ }^{28}$ As a further robustness check, in table A.6 we have restimated the model country by country, finding evidence of a non-linear relationship between support to privatisation and socio-economic status. However the peak of opposition changes from country to country: restricting to statistically significant coefficients, it consists of individuals in "bad" conditions in Bolivia, Brazil, Ecuador, Mexico, Panama, Peru and Venezuela, while the strongest opposition from individual in "average" conditions is found in Columbia, Chile, El Salvador, Guatemala. In the case of Honduras opposition comes from individuals in "very bad" conditions, while for Nicaragua and Uruguay it derives from people in "good" conditions.
} 
change in the social welfare. We take this information seriously, not as a substitute, rather as a complement to more traditional applied welfare economics evaluation, and we try to distil lessons from what respondents say, exploiting several data sets:

1. three large surveys comprising more than 51,000 individuals, expressing their opinion about the consequences of privatisation at country level, as well as judgemenst over the country situation and the virtues of the market; for each interviewee we have information about several individual characteristics (including demographic data, education, occupation, durables owned, residence, language spoken) which we can control for.

2. two databases on specific divestiture/concession events in the countries we study

3. selected macroeconomic variables.

We combine subjective evidence (attitude towards privatisation) from the first type of data with more objective information at country level (macroeconomic controls, features of privatization within the country).

Our key findings are the following ones:

a) disagreement with privatisation is non-linearly related with educational attainment and with socio-economic status, peaking for individual with "uncompleted secondary education" and "bad" socio-economic status. This results points to the frustration of the low-middle classes

b) countries where the public sector is relatively larger are those that record more opposition, probably because of the perceived role of the state in the provision of services and uncertainty about the role of the new private owners.

c) support to privatization declines over time, after controlling for other macroeconomic trends, recent and long privatization processes raise more disagreement

d) privatization discontent is higher when there is an interaction between income inequality in the country and a relatively large proportion of utilities among the government assets divested. Privatisation of public utilities is associated with dissatisfaction whenever individual deprivation is higher, particularly looking at deprivation of 'luxury' goods, a results that again points to the frustration of segments of the middle-to-low classes.

e) respondents tend to dislike privatization more when the private sector commits relatively limited resources in the infrastructure investment, and plays more the role of buyer of divested assets than of active investor in private finance initiatives for creating new infrastructure

f) the relatively limited number, but probably highly visible, distressed contracts in the public utilities, induce an increasing disagreement over time. This points to a learning effect, with a gradual shift of opinion in favour of public-private partnerships or other contracts versus divestitures

g) water and sewerage privatized services raise the highest concern, and this effect is stronger the higher is income inequality in the country. Privatization of water services induces more fierce opposition among those suffering deprivation of basic items, while privatization of electricity raises discontent among those deprived of electric appliances.

Given the robustness of our finding with respect to social status of the respondents (after controlling for macroeconomic trends, and a number of subjective and economic environment variables), and going back to our discussion in the second section, we believe that middle-to-low social status individuals are those who perceive to have suffered most from privatization, particularly of utilities. This result indirectly confirms empirical research at country level, cited in Section 2, that points to regulatory or policy failures in addressing the distributional impact of privatization in Latin America.

Some authors, may claim that in spite of these findings, privatization was beneficial to the poor, and perceptions are mistaken. Given the information available, we are unable to measure which fraction 
of the perceived loss corresponds to actual damage (i.e. it could be converted in monetary terms, and in principle being compensated) and which fraction corresponds just to an imperfect (or even false) perception of damage. We suggest, however, that the non-linear relationship between social discontent and socio-economic status (which survive at country/year sub-sample estimation, and a large set of controls) could not be accounted by a mere false perception of welfare loss. Some components of misperception exist in the data, as witnessed by the "fading memory" of the respondents, but the overall picture is consistent enough and cannot be dismissed just as a collective illusion.

Given the effects of country specific features of privatization, we can summarize our findings in a "recipe" for a successful privatization. First of all, a starting pre-condition is a limited amount of income inequality, which restrains the amount of people suffering from reduced access/higher cost of public utilities. Second, get people acquainted with privatization as much as possible, following a gradual approach (better privatizing in chunks than in a single event). Third, choose an expansionary phase, where output growth compensates for other adverse shocks. Fourth, be careful about the divestiture of public utilities, particularly of water and electicity services, especially where the deprivation of the relatively educated middle classes make the perception of the consequences of privatization more acute. Fifth, and last, turn to alternative ways to attract private finance in the management of infrastructure, and pay attention to the regulatory framework to address the distributive impact of tariff rebalancing.

Conversely, a recipe for troubles and discontent, includes a large and quick divestiture plan, with a high proportion of socially sensitive public services, in a country with high income inequality and suffering adverse macroeconomic shocks, with relatively high educational attainment levels in the population. Our view is that in Latin America these ingredients were often present in many countries, and have contributed to a wide shift in public opinion against privatization. The fact that it is not just the very poor, but a substantial fraction of the middle classes, who perceive to lose from reforms and new market circumstances, is consistent with a strand of research on individual happiness in developing economies (Graham and Pettinato, 2002; Birdsall, Graham and Pettinato, 2005; Graham and Felton, 2005). The privatization story in Latin America reinforces the view that decision-makers, regulators, and applied economists, should consider detailed information on individual welfare changes and redistribution profiles in the context of policy reform, and design suitable interventions targeted to counteract regressive social impacts.

\section{AKNOWLEDGEMENTS}

A previous version of this paper has been presented in conferences and seminars organized by the International Institute of Public Finance, IZA, the American University in Paris, the Italian Society for Public Economics, the Department of Economics, University of Milan, University of La Plata. The authors are very grateful for comments by participants, and for constructive criticism by two anonymous referees, by an Associate Editor, and the Editor of this journal. 


\section{REFERENCES}

Anuatti-Neto F., Barossi-Filho M., Gledson de Carvalho A. and Macedo R. (2003). "Costs and benefits of privatization: Evidence from Brazil", Research Network Working Paper No 455, IADB, June

Aspiazu D. and Schorr M. (2003). "Los impactos regresivos de las privatizaciones en la Argentina: ¿”Errores de diseño” o funcionalidad frente a los intereses del poder económico?”, mimeo.

Banco Interamericano de Desarrollo (BID) (2002). “La paradoja de la privatización”, Políticas Económicas, 2nd. Quarterly, Vol. 18, Research Department.

Barja G., McKenzie D. and Urquiola M. (2002). "Capitalization and privatization in Bolivia”, mimeo, Cornell University.

Barja G. and Urquiola M. (2001), "Capitalization, regulation and the Poor. Access to Basic Services in Bolivia", Discussion Paper No. 2001/34, WIDER, July

Benitez D, Chisari O., Estache A., Can the gains form Argentina's utilities reform offset credit shocks, in Ugaz and Waddams Price (2003)

Birdsall N., Nellis J. (2003), "Winners and losers: assessing the distributional impact of privatization”, Center for global development, wp 6, may 2002, World development 2003

Birdsall N., Graham C., Pettinato S.(2000), Stuck in the Tunnel:is Globalization Muddling the Middle Class?, unpublished

Brau R., Florio M. (2004), "Privatizations as price reforms: an analysis of consumers' welfare change in the UK", in Annales d' Economie et Statistiques, forthcoming.

Calvo G. and Vegh C. (1993), "Exchange rate based stabilizations under imperfect credibility", Cap. 1, Open Economy Macroeconomics, Fishand Worgotter (eds).

Chisari O., Estache A. and Romero C. (1995), "Winners and losers from Utility Privatization in Argentina: Lessons from a General Equilibrium Model”, World Bank

Chisari O., Estache A. and Waddams Price C. (2001), “Access by Poor in Latin America's Utility Reform. Subsidies and Service Obligations", Discussion Paper No. 2001/75, WIDER, September

Chong A. and López de Silanes F. (2003), "The truth about privatization in Latin America", Research Network Working Paper $\mathrm{N}^{\circ}$ 486, IADB.

Cohen R. (2005),'Diagnosis and challenges of economic infrastructure in Latin America",World Bank and Inter-American Development Bank, mimeo, Washington DC

Delfino J. A. and Casarin A. A. (2003), "The reform of the Utilities Sector in Argentina”, in Ugaz and Waddams Price, 2003

Ennis H. and Pinto S. (2002). "Privatization and income distribution in Argentina", mimeo, West Virginia University.

Estache A. (2003), "On Latin America's Infrastructure Privatization and its distributional effects", World Bank and ECARES (Université Libre de Bruxelles), April 30

Estache A., Foster V., Wodon Q. (2002), “Accounting for poverty in infrastructure reform: learning from Latin America's experience”, Washingtron, World Bank, WBI Development studies.

Estache A., Gomez-Lobo A. and Leipziger D. (2000), "Utilities privatization and the needs of the poor in Latin America. Heve we learned enough to get it right?", Infrastructure for Development: Private Solutions and the Poor, 31 May-2 June 2000, London, UK 
Fischer R; Gutierrez R. and Serra P. (2003), "The effects of privatization on firms and on social welfare: The Chilean case", Research Network Working Paper No 456, IADB, May

Florio M. (2004), The Great Divestiture. Evaluating the welfare impact of British privatizations 1979-1997, forthcoming, The MIT Press.

Forteza A., Tommasi M. (2005), "Understanding reform in Latin America”, Global Development Network, unpublished

Freije S. and Rivas L. (2002). "Privatization, inequality, and welfare: Evidence from Nicaragua", mimeo, IESA, Venezuela.

Galal et al. (1994), Welfare consequences of selling public enterprises, an empirical analysis, Oxford University Press for the World Bank, Washington DC

Galiani S., Gertler P., Schargrodsky E. and Sturzenegger F. (2003), "The costs and benefits of privatization in Argentina: A microeconomic analysis", Research Network Working Paper No. 454, IADB, April

Ganuza E. Paez de Barro R. and Vos R. (2001), "Efectos de la liberalización sobre la pobreza y la desigualdad" in Ganuza, E.; Paez de Barro, R.; Taylor, L. and Vos R. (eds) liberalización, desigualdad y pobreza: América Latina y el Caribe en los 90. Edudeba, CEPAL y PNUD.

Garrón, M., Machicado C. and Capra K. (2003), "Privatization in Bolivia: the Impact on firm performance", Research Network Working Paper No. 461, IABD, October

Graham C., Felton A. (2005), "Does inequality matter in individual welfare? An Initial Exploration Based on Happiness Surveys from Latin America”, The Brookings Institution, unpublished

Graham C., Pettinato S. (2002), "Frustrated Achievers: Winners, Losers, and Subjective Well Being in New market Economies", in Journal of Development Studies, April.

Guash L. ( 2004 ) Granting and renegotiating infrastructure concessions: Doing it Right, WBI Development studies, Washington DC

Hancock R, Waddams Price C. (1998), "Distributional effects of liberalising UK residential markets", Fiscal Studies, Vol 19, N. 3, 295-319.

Harris C. (2003), "Private participation in infrastructure in developing countries: Trends, impacts, and policy lessons", Clive Harris Private Sector Advisory Services.

Kessides I.N. (2004), "Reforming infrastructure. Privatization, Regulation, and Competition", World Bank Research Report, Washington DC

La Porta. R. and López de Silanes F. (1999), "The benefits of privatization: Evidence from Mexico", Quarterly Journal of Economics 4, 1193-1242

Latinobarometro, Providencia-Santiago- Chile, 2002, www.latinobarometro.org

López-Calva L.F. and Rosellón J. (2002), "Privatization and inequality: The Mexican case", mimeo, Universidad de las Américas-Puebla.

Lora E. (2001), "Structural Reforms in Latin America: What has beeen reformed and how to measure it", Working Paper No. 466, Research Department, IABD, December

Lora E. And Panizza U. (2002), "Structural Reforms in Latin America under Scrutiny", Working Paper No. 470, Research Department, IABD, March

McCoy J; Davis J. and Foote P. (1998), "Reluctant reformers: Explaining privatization in Venezuela and Uruguay", Congress of the Latin American Studies Association, Chicago, September 24. 
McKenzie D., Mookherjee D. (2003), "The distributive impact of Privatization in Latin America: Evidence from four countries”, Discussion paper 128, Institute for Economic Development, February.

Megginson W., Netter J. (2001), "From state to market: a survey of empirical studies on privatization”, in Journal of Economic Literature, 39(3), pp 321-389.

Megginson W. and Netter J. (2000), "From state to market: A survey of empirical studies on privatization", Social Science Research Network Electronic Paper Collection.

Murillo V. (2002), "Political bias in policy convergence. Privatization choices in Latin America". Yale University, Department of Political Science, mimeo

Nellis, J. (2003), "Privatization in Latin America" Center for Global Development WP 31, August.

Nellis J., Menezes R. and Lucas S. (2004), "Privatization in Latin America. The rapid rise, recent fall, and continuing puzzle of a contentious economic policy", Policy Brief Volume 3, Issue 1, Center for Global Development, January

Panizza U. and M.Yañez 2003. Why Are Latin Americans So Unhappy about Reforms? mimeo

Lora, E., Panizza, U. and M.Quispe-Agnoli. 2004. Reform fatigue: Symptoms, Reasons and Implications. Federal Reserve Bank of Atalanta Economic Review, second Quarter: 1-28

Paredes R.M. (2001), "Redistributive Impact of Privatization and the Regulation of Utilities in Chile", Discussion Paper No. 2001/19, WIDER, June

Pombo C. and Ramírez M. (2003). "Privatization in Colombia: A plant performance analysis", Research Network Working Paper No. 458, IADB, June

Privatization International, Privatization Yearbook, various years, 1990-2000, London

Sader F. (1993), "Privatizing Public Enterprises and Foreign Investment in Developing Countries, 1988-93”, Foreign Investment Advisory Service Occasional Paper 5, Washington, DC, United States: World Bank

Taylor L. and Vos R. (2001), "Liberalización de la balanza de pagos en América Latina. Efectos sobre el crecimiento, la distribución y la pobreza" in Ganuza, E.; Paez de Barro, R.; Taylor, L. and Vos R. (eds.) liberalización, desigualdad y pobreza: América Latina y el Caribe en los 90. Eudeba, CEPAL y PNUD.

The Economist, Democracy clings in a cold economic climate. Latinobarometro poll. August 17 2002, 41-42

The Economist, The stubborn survival of frustrated democrats. The Latinobarometro poll. November $1^{\text {st }} 2003,53-54$

The World Bank, Inequality in Latin America and the Caribbean: breaking with history?, advance conference edition, World bank Latin America and Caribbean Studies,2003.

The World Bank, Making services work for poor people, World Development report, 2004

The World Bank, World Development Indicators 2003, Washington April 2003

Torero M. (2003). "Peruvian privatization: Impacts on firm performance", Research Network Working Paper $N^{\circ} 481$, IADB, December

Torero M. and Pascó-Font A. (2001), "The social impact of Privatization and the Regulation of Utilities in Peru", Discussion Paper No. 2001/17, WIDER, June

Trujillo L., Martin N., Estache A and Campos J. (2002), "Macroeconomic effects of private participation in Latin America`s infrastructure", World Bank Policy Research WP, October. 
Ugaz C. (2002), "Consumer participation and Pro-Poor regulation in Latin America", Discussion Paper No. 2002/121, WIDER, December

Ugaz C. and Waddams Price C. (2003), "Utility Privatization and Regulation: a Fair Deal for Consumers?", Edward Elgar: Cheltenham

Williamson J. (1990), "What Washington means by policy reform", in J. Williamson (ed), Latin American Adjustment. How much has happened, Washington DC, Institute for International Economics.

Williamson, J. (1990), "What Washington means by policy reform" in J. Williamson (ed), Latina American adjustment. How much has happened, Washington DC, Institute for International Economics.

Williamson J. (2000), What should the World Bank think about the Washington Consensus, in The World Bank research observer, August. 


\section{TABLES}

Table 1 - Attitude towards privatization - Latin America 1998-2000-2002

\begin{tabular}{l|cc|cc|cc|cc}
$\begin{array}{l}\text { Privatization has been } \\
\text { beneficial to the }\end{array}$ & \multicolumn{2}{|c|}{1998} & \multicolumn{2}{c|}{2000} & \multicolumn{2}{c|}{2002} & \multicolumn{2}{c}{ entire sample } \\
indiv & $\%$ & indiv & $\%$ & indiv & $\%$ & \\
country & & & & & & & & \\
\hline strongly disagree & 2.382 & 13.35 & 3.570 & 19.79 & 4.441 & 23.98 & 10.393 \\
somewhat disagree & 5.417 & 30.37 & 6.684 & 37.06 & 6.993 & 37.76 & 19.094 & 35.10 \\
don't know & 1.354 & 7.59 & 1.202 & 6.66 & 1.271 & 6.86 & 3.827 & 7.04 \\
somewhat agree & 6.260 & 35.09 & 4.577 & 25.37 & 3.781 & 20.41 & 14.618 & 26.87 \\
strongly agree & 1.992 & 11.17 & 1.832 & 10.16 & 1.573 & 8.49 & 5.397 & 9.92 \\
non respondent & 434 & 2.43 & 173 & 0.96 & 463 & 2.50 & 1.070 & 1.97 \\
\hline Total & 17.839 & 100.00 & 18.038 & 100.00 & 18.522 & 100.00 & 54.399 & 100.00
\end{tabular}

Table 2 -Other related social attitudes - percent - Latin America 1998-2000-2002

\begin{tabular}{l|ccc} 
How would you describe the present economic & 1998 & 2000 & 2002 \\
situation of the country? & & & \\
\hline Very Bad & 17.51 & 15.88 & 20.43 \\
Bad & 34.72 & 35.67 & 36.40 \\
About average & 38.88 & 39.07 & 35.42 \\
Good & 7.50 & 8.02 & 6.97 \\
Very Good & 1.39 & 1.36 & 0.78 \\
\hline & & & \\
The market economy is best for the country. & 1998 & 2000 & 2002 \\
\hline strongly disagree & 4.55 & 8.57 & 8.01 \\
somewhat disagree & 15.75 & 19.86 & 17.81 \\
don't know & 10.78 & 13.24 & 12.85 \\
somewhat agree & 48.05 & 40.01 & 44.13 \\
strongly agree & 20.87 & 18.32 & 17.20 \\
\hline & & & \\
The State should leave economic activity to the & 1998 & 2000 & 2002 \\
private sector. & & & \\
\hline strongly disagree & 10.34 & n.a. & 17.37 \\
somewhat disagree & 30.75 & n.a. & 37.48 \\
don't know & 6.85 & n.a. & 7.91 \\
somewhat agree & 37.56 & n.a. & 27.80 \\
strongly agree & 14.50 & n.a. & 9.44 \\
\hline
\end{tabular}

Table 3 - Changes in consumer surplus - Argentina - USD (1999)

\begin{tabular}{|l|c|c|c|c|c|c|c|c|c|c|c|}
\hline Income group & \multicolumn{2}{|c|}{ Telecoms } & \multicolumn{2}{|c|}{ Electricity } & \multicolumn{2}{c|}{ Gas } & \multicolumn{2}{c|}{$\begin{array}{l}\text { Water and } \\
\text { sewerage }\end{array}$} & \multicolumn{3}{c|}{ Total } \\
& & & & & & & & \\
& DS & DS/Y & DS & DS/Y & DS & DS/Y & DS & DS/Y & DS & DS/Y & E/Y \\
\hline Average & 70.6 & 0.33 & 29.2 & 0.12 & -22.8 & -0.16 & -48.6 & -0.10 & 28.4 & 0.18 & 7.6 \\
\hline $1^{\text {st }}$ quintile(poorest) & 9.6 & 0.27 & -0.4 & -0.06 & -15.2 & -0.35 & -45.8 & -1.85 & -51.8 & -1.27 & 16.7 \\
\hline $2^{\text {nd }}$ quintile & 30.1 & 0.31 & 14.6 & 0.15 & -18.5 & -0.20 & -47.2 & -0.97 & -21 & -0.27 & 9.6 \\
\hline $3^{\text {rd }}$ quintile & 54.8 & 0.39 & 26.9 & 0.19 & -21.6 & -0.15 & -48.1 & -0.66 & 12 & 0.00 & 7.0 \\
\hline $4^{\text {th }}$ quintile & 75.5 & 0.35 & 39.6 & 0.19 & -24.2 & -0.11 & -48.3 & -0.44 & 42.3 & 0.25 & 5.3 \\
\hline $5^{\text {th }}$ quintile(richest) & 131.5 & 0.30 & 61.5 & 0.15 & -29.5 & -0.07 & -51.15 & -0.22 & 112 & 0.33 & 3.4 \\
\hline
\end{tabular}

Source: adapted from Delfino and Casarin (2003,tab. 7.2, p.161 and tab 7.3, p. 165) and our own calculations (total impact). Tariffs at December 1999, USD, before taxes, consumption data 1996-97 from Instituto Nacional de Estadistica y Censos, Statistical yearbook, Buenos Aires 2000. DS $=\mathrm{E}_{1}\left[\left(\mathrm{P}_{1}-\mathrm{P}_{2}\right) / \mathrm{P}_{1}\right]\left[1+0,5 \varepsilon\left[\left(\mathrm{P}_{1}-\mathrm{P}_{2}\right) / \mathrm{P}_{1}\right]\right]$, where $\mathrm{E}_{1}$ is initial expenditure level, $\mathrm{E}_{2}$ final expenditure level, $\mathrm{Y}$ adjusted household income, $\varepsilon$ price elasticity (assumed to be -1 for telecoms, $-0,5$ for electricity and gas, and 0 for water and sewerage in the reference scenario). 
Table 4 - Attitude towards privatization: "The privatisation of state companies has been beneficial to the country" by country and years - percent - Latin America 1998-2000-2002

\begin{tabular}{|c|c|c|c|c|c|c|c|}
\hline Country & & $\begin{array}{l}\text { strongly } \\
\text { disagree }\end{array}$ & $\begin{array}{c}\begin{array}{c}\text { somewhat } \\
\text { disagree }\end{array} \\
\end{array}$ & uncertain & $\begin{array}{c}\text { somewhat } \\
\text { agree }\end{array}$ & strongly agree & $\begin{array}{c}\text { number of } \\
\text { observations }\end{array}$ \\
\hline \multirow[t]{3}{*}{ Argentina } & 1998 & 21.43 & 27.72 & 10.71 & 33.42 & 6.72 & 1176 \\
\hline & 2000 & 36.03 & 31.94 & 4.42 & 20.43 & 7.17 & 1199 \\
\hline & 2002 & 45.16 & 38.81 & 2.34 & 11.94 & 1.75 & 1198 \\
\hline \multirow[t]{3}{*}{ Bolivia } & 1998 & 10.25 & 30.09 & 5.39 & 43.23 & 11.04 & 761 \\
\hline & 2000 & 16.26 & 42.29 & 6.41 & 27.79 & 7.25 & 1076 \\
\hline & 2002 & 18.16 & 53.91 & 3.91 & 19.38 & 4.64 & 1228 \\
\hline \multirow[t]{3}{*}{ Brasil } & 1998 & 8.82 & 35.80 & 5.68 & 37.53 & 12.17 & 986 \\
\hline & 2000 & 25.97 & 35.85 & 5.50 & 24.44 & 8.25 & 982 \\
\hline & 2002 & 38.22 & 14.14 & 8.91 & 22.23 & 16.50 & 976 \\
\hline \multirow[t]{3}{*}{ Chile } & 1998 & 12.59 & 28.55 & 8.23 & 39.04 & 11.59 & 1191 \\
\hline & 2000 & 18.28 & 39.71 & 7.65 & 29.00 & 5.36 & 1176 \\
\hline & 2002 & 22.89 & 45.61 & 5.91 & 21.03 & 4.56 & 1184 \\
\hline \multirow[t]{3}{*}{ Colombia } & 1998 & 17.25 & 35.10 & 7.77 & 28.27 & 11.61 & 1171 \\
\hline & 2000 & 27.57 & 34.59 & 6.52 & 24.39 & 6.93 & 1197 \\
\hline & 2002 & 25.85 & 38.77 & 12.66 & 18.39 & 4.34 & 1153 \\
\hline \multirow[t]{3}{*}{ Costarica } & 1998 & 7.33 & 21.05 & 9.08 & 51.91 & 10.63 & 969 \\
\hline & 2000 & 13.04 & 37.01 & 9.67 & 25.45 & 14.83 & 951 \\
\hline & 2002 & 13.99 & 40.35 & 13.28 & 24.62 & 7.76 & 979 \\
\hline \multirow[t]{3}{*}{ Ecuador } & 1998 & 10.59 & 30.38 & 5.03 & 38.89 & 15.10 & 1152 \\
\hline & 2000 & 13.71 & 39.85 & 6.18 & 29.02 & 11.25 & 1182 \\
\hline & 2002 & 18.43 & 31.57 & 4.58 & 32.44 & 12.98 & 1156 \\
\hline \multirow[t]{3}{*}{ El salvador } & 1998 & 11.52 & 32.42 & 1.92 & 37.37 & 16.77 & 990 \\
\hline & 2000 & 17.97 & 38.05 & 8.84 & 19.48 & 15.66 & 996 \\
\hline & 2002 & 13.07 & 42.68 & 6.22 & 27.40 & 10.64 & 949 \\
\hline \multirow[t]{3}{*}{ Guatemala } & 1998 & 2.73 & 33.30 & 1.62 & 50.10 & 12.25 & 988 \\
\hline & 2000 & 23.86 & 41.39 & 4.36 & 21.06 & 9.34 & 964 \\
\hline & 2002 & 31.01 & 33.88 & 6.45 & 19.04 & 9.62 & 977 \\
\hline \multirow[t]{3}{*}{ Honduras } & 1998 & 10.74 & 25.24 & 13.21 & 38.02 & 12.78 & 931 \\
\hline & 2000 & 14.13 & 38.14 & 5.05 & 23.92 & 18.77 & 991 \\
\hline & 2002 & 19.70 & 38.17 & 6.09 & 21.02 & 15.03 & 985 \\
\hline \multirow[t]{3}{*}{ México } & 1998 & 14.81 & 24.68 & 9.87 & 34.04 & 16.60 & 1175 \\
\hline & 2000 & 19.71 & 36.14 & 6.63 & 31.67 & 5.85 & 1162 \\
\hline & 2002 & 24.71 & 43.12 & 3.32 & 23.88 & 4.98 & 1206 \\
\hline \multirow[t]{3}{*}{ Nicaragua } & 1998 & 9.48 & 37.72 & 6.52 & 32.21 & 14.07 & 981 \\
\hline & 2000 & 7.02 & 44.73 & 5.12 & 28.49 & 14.64 & 997 \\
\hline & 2002 & 27.02 & 35.18 & 6.55 & 14.72 & 16.53 & 992 \\
\hline \multirow[t]{3}{*}{ Panamá } & 1998 & 40.40 & 36.68 & 2.71 & 17.29 & 2.91 & 995 \\
\hline & 2000 & 27.40 & 48.84 & 1.82 & 14.66 & 7.28 & 989 \\
\hline & 2002 & 27.75 & 33.20 & 7.71 & 15.21 & 16.14 & 973 \\
\hline \multirow[t]{3}{*}{ Paraguay } & 1998 & 7.93 & 28.62 & 15.52 & 39.66 & 8.28 & 580 \\
\hline & 2000 & 20.43 & 39.20 & 3.16 & 23.92 & 13.29 & 602 \\
\hline & 2002 & 26.42 & 48.49 & 6.52 & 15.89 & 2.68 & 598 \\
\hline \multirow[t]{3}{*}{ Perú } & 1998 & 10.22 & 39.68 & 4.86 & 38.39 & 6.85 & 1008 \\
\hline & 2000 & 13.85 & 43.46 & 4.90 & 32.50 & 5.29 & 1040 \\
\hline & 2002 & 12.26 & 45.59 & 9.24 & 27.88 & 5.04 & 1191 \\
\hline \multirow[t]{3}{*}{ Uruguay } & 1998 & 19.97 & 36.50 & 13.28 & 24.76 & 5.48 & 1167 \\
\hline & 2000 & 29.92 & 27.31 & 15.04 & 23.78 & 3.95 & 1190 \\
\hline & 2002 & 34.78 & 37.34 & 12.28 & 11.94 & 3.67 & 1173 \\
\hline \multirow[t]{3}{*}{ Venezuela } & 1998 & 10.81 & 25.51 & 11.57 & 34.46 & 17.65 & 1184 \\
\hline & 2000 & 11.53 & 23.23 & 10.08 & 32.37 & 22.80 & 1171 \\
\hline & 2002 & 18.93 & 35.58 & 4.73 & 26.64 & 14.11 & 1141 \\
\hline \multirow[t]{3}{*}{ Total } & 1998 & 13.69 & 31.12 & 7.78 & 35.97 & 11.44 & 17405 \\
\hline & 2000 & 19.98 & 37.41 & 6.73 & 25.62 & 10.25 & 17865 \\
\hline & 2002 & 24.59 & 38.72 & 7.04 & 20.94 & 8.71 & 18059 \\
\hline
\end{tabular}


Table 5 - Self-assessed socio-economic status and deprivation - percent - Latin America 1998-2000-2002

\begin{tabular}{l|ccccc|c} 
Lack of & Very Bad & Bad & $\begin{array}{c}\text { About } \\
\text { average }\end{array}$ & Good & $\begin{array}{c}\text { Very } \\
\text { Good }\end{array}$ & $\begin{array}{c}\text { sample } \\
\text { average }\end{array}$ \\
\hline color tv set & 42.29 & 26.37 & 9.75 & 3.13 & 2.52 & 10.44 \\
refrigerator/ice box/freezer & 56.10 & 39.44 & 17.81 & 6.60 & 4.73 & 17.38 \\
housing & 41.70 & 35.82 & 28.08 & 18.97 & 12.89 & 25.34 \\
computer & 95.17 & 95.56 & 89.89 & 72.96 & 46.44 & 81.61 \\
washing machine & 84.72 & 75.40 & 59.15 & 39.22 & 24.32 & 52.79 \\
telephone & 78.05 & 70.77 & 49.67 & 24.23 & 13.27 & 42.11 \\
car & 89.03 & 86.83 & 76.68 & 55.31 & 30.92 & 67.59 \\
second home for holiday & 95.53 & 94.60 & 91.44 & 84.64 & 68.17 & 87.84 \\
drink water & 26.97 & 16.04 & 8.77 & 5.55 & 4.40 & 9.00 \\
hot water & 80.58 & 71.87 & 59.70 & 45.29 & 34.54 & 55.23 \\
sewage system & 49.36 & 34.97 & 23.09 & 14.86 & 11.16 & 21.92 \\
\hline How do you cover your health expenses $?$ & & & & & \\
Private insurance & 7.83 & 10.47 & 16.26 & 30.89 & 47.11 & 22.63 \\
Public insurance & 35.41 & 38.72 & 43.21 & 41.60 & 32.29 & 40.84 \\
No insurance & 56.76 & 50.81 & 40.53 & 27.51 & 20.60 & 36.53 \\
\hline Sample distribution: & & & & & & \\
1998 & 2.99 & 11.99 & 40.00 & 36.24 & 8.77 & 100.00 \\
2000 & 3.42 & 14.49 & 41.73 & 32.37 & 7.99 & 100.00 \\
2002 & 4.13 & 16.54 & 38.71 & 32.33 & 8.29 & 100.00
\end{tabular}


Table 6 - Descriptive statistics of individual variables (sample weights) - Latin America 19982000-2002

\begin{tabular}{lcccccc} 
Variable & & Obs & Mean & Std.Dev. & Min & Max \\
\hline age & 1998 & 17400 & 38.45 & 15.23 & 16 & 98 \\
& 2000 & 17865 & 38.33 & 15.58 & 18 & 99 \\
& 2002 & 18045 & 38.91 & 16.22 & 16 & 99 \\
\hline attitude towards privatisation & 1998 & 17405 & 0.00 & 1.29 & -2 & 2 \\
& 2000 & 17865 & -0.33 & 1.32 & -2 & 2 \\
& 2002 & 18045 & -0.50 & 1.29 & -2 & 2 \\
\hline years of education & 1998 & 16839 & 9.81 & 4.13 & 0 & 16 \\
& 2000 & 17865 & 9.67 & 4.32 & 0 & 16 \\
& 2002 & 18045 & 7.81 & 4.42 & 0 & 16 \\
\hline female & 1998 & 17405 & 0.51 & 0.50 & 0 & 1 \\
& 2000 & 17865 & 0.51 & 0.50 & 0 & 1 \\
\hline chief income earner & 2002 & 18045 & 0.52 & 0.50 & 0 & 1 \\
& 1998 & 17405 & 0.51 & 0.50 & 0 & 1 \\
& 2000 & 17865 & 0.49 & 0.50 & 0 & 1 \\
socio-economic level & 2002 & 18045 & 0.50 & 0.50 & 0 & 1 \\
\hline & 1998 & 17137 & 0.35 & 0.91 & -2 & 2 \\
& 2000 & 17860 & 0.26 & 0.93 & -2 & 2 \\
& 2002 & 18045 & 0.18 & 0.97 & -2 & 2 \\
\hline
\end{tabular}

\begin{tabular}{lccc} 
educational attainment & Freq. & Percent & Cum. \\
\hline Illiterate & 3157 & 5.98 & 5.98 \\
Primary uncompleted & 10409 & 19.73 & 25.72 \\
Primary complete & 6380 & 12.09 & 37.81 \\
Secondary uncompleted & 10382 & 19.68 & 57.49 \\
Secondary complete & 12084 & 22.91 & 80.4 \\
University uncompleted & 5682 & 10.77 & 91.17 \\
University complete & 4656 & 8.83 & 100 \\
\hline Total & 52749 & 100 & \\
& & & \\
condition & Freq. & Percent & Cum. \\
\hline self-employed & 15476 & 29.29 & 29.29 \\
employed public sector & 4840 & 9.16 & 38.46 \\
employed private sector & 9341 & 17.68 & 56.14 \\
unemployed & 3611 & 6.83 & 62.97 \\
retired & 3729 & 7.06 & 70.03 \\
housewife & 10833 & 20.51 & 90.54 \\
student & 5000 & 9.46 & 100 \\
\hline Total & 52829 & 100 &
\end{tabular}


Table 7 - Determinants of support for privatization - Latin America 1998-2000-2002

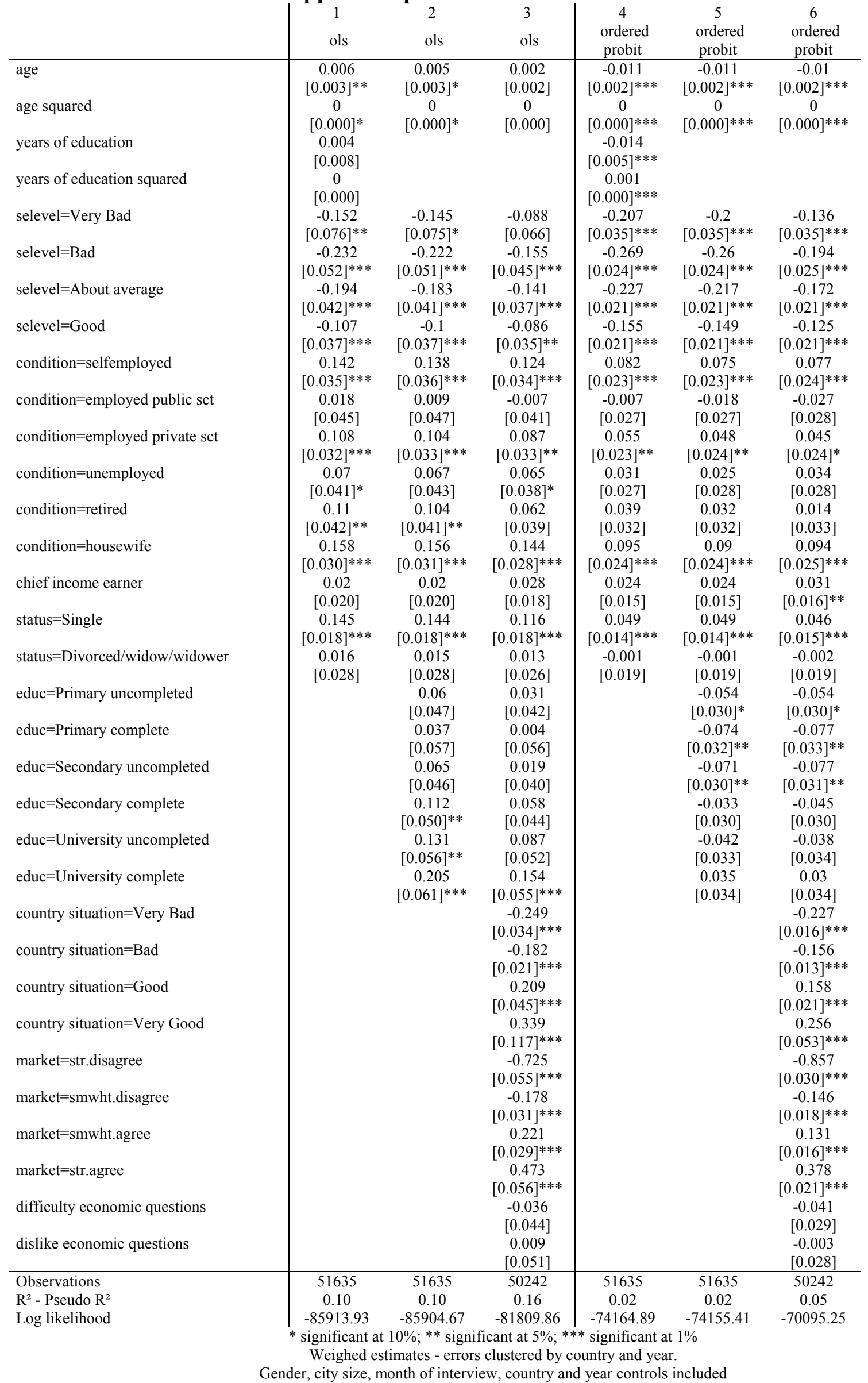


Table 8 - Cumulative deprivation (sample weights) - Latin America 1998-2000-2002

\begin{tabular}{c|ccc|ccc|ccc||}
$\begin{array}{c}\text { number of } \\
\text { items to be } \\
\text { deprived }\end{array}$ & \multicolumn{2}{|c|}{\begin{tabular}{c}
\multicolumn{2}{|c|}{ basic durables (housing, drinking } \\
water, hot water and sewage)
\end{tabular}} & \multicolumn{2}{c|}{$\begin{array}{c}\text { electric durables (colour TV set, } \\
\text { refrigerator, washing machine } \\
\text { and telephone) }\end{array}$} & \multicolumn{2}{c|}{$\begin{array}{c}\text { luxury durables (computer, car } \\
\text { and second home) }\end{array}$} \\
\hline 0 & 1998 & 2000 & 2002 & 1998 & 2000 & 2002 & 1998 & 2000 & 2002 \\
1 & 33.46 & 30.24 & 25.04 & 38.32 & 36.26 & 30.04 & 5.29 & 5.19 & 2.96 \\
2 & 40.39 & 39.90 & 36.14 & 28.74 & 30.24 & 24.15 & 12.30 & 12.62 & 10.04 \\
3 & 18.18 & 20.92 & 24.41 & 19.17 & 19.42 & 21.59 & 25.68 & 24.15 & 20.88 \\
4 & 5.98 & 6.80 & 11.55 & 8.25 & 8.70 & 13.10 & 56.73 & 58.04 & 66.12 \\
& 2.00 & 2.15 & 2.85 & 5.53 & 5.37 & 11.12 & & &
\end{tabular}

Table 9 - Descriptive statistics of country features of privatization - Latin America 1990-2001 - Source: FEEM, PrivatizationBarometer, Securities Data Corp.

\begin{tabular}{|c|c|c|c|c|c|c|c|c|c|c|}
\hline & & $\begin{array}{l}\text { attitude } \\
\text { (mean) }\end{array}$ & $\begin{array}{l}\text { number of } \\
\text { event per } \\
\text { month } \\
\text { (frequency) }\end{array}$ & $\begin{array}{c}\text { duration } \\
\text { (number } \\
\text { of } \\
\text { months) }\end{array}$ & $\begin{array}{l}\text { share of } \\
\text { public } \\
\text { utilities } \\
\text { (shuti) }\end{array}$ & $\begin{array}{l}\text { proceedings } \\
\text { over GDP } \\
\text { (incidence) }\end{array}$ & $\begin{array}{c}\text { growth } \\
\text { rate of } \\
\text { GDP } \\
\text { (last } 3 \\
\text { yrs) }\end{array}$ & $\begin{array}{l}\text { gini index } \\
\text { on income } \\
\text { inequality }\end{array}$ & $\begin{array}{l}\text { illiteracy } \\
\text { rate in } \\
\text { adult } \\
\text { population }\end{array}$ & $\begin{array}{c}\text { share of } \\
\text { public } \\
\text { expendt } \\
\text { over GDP } \\
\text { (pubexp) }\end{array}$ \\
\hline \multirow[t]{3}{*}{ Argentina } & $1990-97$ & -0.24 & 0.75 & 107 & 0.68 & 1.05 & 0.21 & 0.48 & 0.04 & 0.09 \\
\hline & 1998-99 & -0.69 & 0.60 & 107 & 0.14 & 1.14 & -0.02 & 0.50 & 0.03 & 0.13 \\
\hline & 2000-01 & -1.14 & 0.00 & 107 & 0.00 & 0.00 & -0.03 & 0.52 & 0.03 & 0.14 \\
\hline \multirow[t]{3}{*}{ Bolivia } & $1990-97$ & 0.15 & 1.00 & 89 & 0.08 & 2.54 & 0.07 & 0.60 & 0.19 & 0.13 \\
\hline & 1998-99 & -0.33 & 0.33 & 89 & 0.00 & 1.12 & 0.03 & 0.60 & 0.15 & 0.14 \\
\hline & 2000-01 & -0.62 & 0.00 & 89 & 0.00 & 0.00 & -0.02 & 0.63 & 0.14 & 0.16 \\
\hline \multirow[t]{3}{*}{ Brasil } & $1990-97$ & 0.08 & 0.47 & 154 & 0.67 & 0.19 & 0.08 & 0.60 & 0.17 & 0.18 \\
\hline & $1998-99$ & -0.47 & 0.83 & 154 & 0.27 & 0.88 & -0.17 & 0.60 & 0.15 & 0.18 \\
\hline & 2000-01 & -0.35 & 0.54 & 154 & 0.10 & 0.83 & -0.02 & 0.61 & 0.15 & 0.18 \\
\hline \multirow[t]{3}{*}{ Chile } & $1990-97$ & 0.08 & 0.21 & 99 & 0.47 & 0.18 & 0.14 & 0.54 & 0.05 & 0.10 \\
\hline & $1998-99$ & -0.37 & 0.54 & 99 & 0.65 & 1.56 & -0.01 & 0.57 & 0.04 & 0.11 \\
\hline & 2000-01 & -0.61 & 0.08 & 99 & 1.00 & 0.32 & -0.04 & 0.60 & 0.04 & 0.12 \\
\hline \multirow[t]{3}{*}{ Colombia } & $1990-97$ & -0.18 & 0.17 & 97 & 0.86 & 0.53 & 0.14 & 0.56 & 0.10 & 0.13 \\
\hline & 1998-99 & -0.51 & 0.30 & 97 & 0.99 & 0.77 & -0.11 & 0.56 & 0.09 & 0.22 \\
\hline & 2000-01 & -0.63 & 0.00 & 97 & 0.00 & 0.00 & -0.01 & 0.57 & 0.08 & 0.19 \\
\hline \multirow[t]{3}{*}{ Ecuador } & $1990-97$ & 0.18 & 0.02 & 1 & 0.00 & 0.02 & 0.09 & 0.56 & 0.11 & 0.10 \\
\hline & 1998-99 & -0.16 & 0.00 & 1 & 0.00 & 0.00 & -0.02 & 0.56 & 0.09 & 0.11 \\
\hline & 2000-01 & -0.10 & 0.00 & 1 & 0.00 & 0.00 & -0.28 & 0.56 & 0.08 & 0.09 \\
\hline \multirow[t]{3}{*}{ El salvador } & $1990-97$ & 0.15 & 1.00 & 8 & 1.00 & 0.04 & 0.12 & 0.52 & 0.25 & 0.09 \\
\hline & 1998-99 & -0.23 & 0.75 & 8 & 0.53 & 3.77 & 0.06 & 0.53 & 0.22 & 0.10 \\
\hline & 2000-01 & -0.20 & 0.00 & 8 & 0.00 & 0.00 & 0.05 & 0.54 & 0.21 & 0.10 \\
\hline \multirow[t]{3}{*}{ Guatemala } & $1990-97$ & 0.36 & 0.25 & 21 & 1.00 & 0.02 & 0.10 & 0.49 & 0.36 & 0.06 \\
\hline & $1998-99$ & -0.49 & 0.18 & 21 & 0.40 & 4.04 & 0.02 & 0.49 & 0.32 & 0.06 \\
\hline & 2000-01 & -0.58 & 0.00 & 21 & 0.00 & 0.00 & 0.07 & 0.52 & 0.31 & 0.07 \\
\hline \multirow[t]{3}{*}{ Honduras } & $1990-97$ & 0.17 & 0.00 & 1 & 0.00 & 0.00 & 0.04 & 0.59 & 0.29 & 0.11 \\
\hline & $1998-99$ & -0.05 & 0.04 & 1 & 0.00 & 0.00 & 0.07 & 0.59 & 0.26 & 0.11 \\
\hline & 2000-01 & -0.26 & 0.00 & 1 & 0.00 & 0.00 & 0.09 & 0.58 & 0.25 & 0.13 \\
\hline \multirow[t]{3}{*}{ México } & $1990-97$ & 0.13 & 0.47 & 159 & 0.00 & 0.41 & 0.09 & 0.53 & 0.11 & 0.10 \\
\hline & $1998-99$ & -0.32 & 0.42 & 159 & 0.00 & 0.16 & 0.10 & 0.55 & 0.09 & 0.11 \\
\hline & 2000-01 & -0.59 & 0.17 & 159 & 0.00 & 0.17 & 0.14 & 0.54 & 0.09 & 0.11 \\
\hline \multirow[t]{3}{*}{ Panamá } & $1990-97$ & -0.94 & 0.07 & 97 & 0.00 & 0.91 & 0.07 & 0.56 & 0.10 & 0.15 \\
\hline & $1998-99$ & -0.74 & 0.21 & 97 & 0.95 & 1.43 & 0.15 & 0.58 & 0.09 & 0.14 \\
\hline & 2000-01 & -0.41 & 0.00 & 97 & 0.00 & 0.00 & 0.03 & 0.58 & 0.08 & 0.15 \\
\hline \multirow[t]{3}{*}{ Paraguay } & $1990-97$ & 0.12 & 0.05 & 38 & 0.00 & 0.07 & 0.11 & 0.53 & 0.09 & 0.07 \\
\hline & 1998-99 & -0.30 & 0.00 & 38 & 0.00 & 0.00 & -0.10 & 0.58 & 0.07 & 0.09 \\
\hline & 2000-01 & -0.80 & 0.00 & 38 & 0.00 & 0.00 & -0.06 & 0.58 & 0.07 & 0.10 \\
\hline \multirow[t]{3}{*}{ Perú } & $1990-97$ & -0.08 & 0.95 & 119 & 0.29 & 1.10 & 0.16 & 0.43 & 0.13 & 0.09 \\
\hline & 1998-99 & -0.28 & 0.13 & 119 & 0.00 & 0.08 & -0.07 & 0.51 & 0.11 & 0.11 \\
\hline & 2000-01 & -0.32 & 0.13 & 119 & 0.73 & 0.29 & 0.03 & 0.49 & 0.10 & 0.11 \\
\hline \multirow[t]{3}{*}{ Uruguay } & $1990-97$ & -0.41 & 0.04 & 88 & 0.00 & 0.02 & 0.12 & 0.43 & 0.03 & 0.12 \\
\hline & 1998-99 & -0.55 & 0.00 & 88 & 0.00 & 0.00 & -0.01 & 0.44 & 0.02 & 0.13 \\
\hline & 2000-01 & -0.88 & 0.04 & 88 & 0.00 & 0.05 & -0.06 & 0.44 & 0.02 & 0.13 \\
\hline \multirow[t]{3}{*}{ Venezuela } & $1990-97$ & 0.23 & 0.43 & 98 & 0.00 & 0.80 & 0.10 & 0.49 & 0.10 & 0.08 \\
\hline & 1998-99 & 0.32 & 0.63 & 98 & 0.04 & 1.13 & 0.08 & 0.48 & 0.08 & 0.08 \\
\hline & 2000-01 & -0.19 & 0.00 & 98 & 0.00 & 0.00 & 0.11 & 0.46 & 0.07 & 0.07 \\
\hline \multirow[t]{3}{*}{ Total } & 1990-97 & 0.00 & 0.39 & 80.66 & 0.34 & 0.50 & 0.11 & 0.53 & 0.14 & 0.11 \\
\hline & 1998-99 & -0.31 & 0.34 & 80.67 & 0.27 & 1.06 & 0.00 & 0.54 & 0.12 & 0.12 \\
\hline & $2000-01$ & -0.50 & 0.06 & 81.28 & 0.13 & 0.11 & 0.00 & 0.55 & 0.11 & 0.12 \\
\hline
\end{tabular}


Table 10 - Descriptive statistics of country features of privatization - Latin America 19842002 - Source: Private Participation in Infrastructure Database, The World Bank Group

\begin{tabular}{|c|c|c|c|c|c|c|c|c|c|c|c|}
\hline & & $\begin{array}{l}\text { attitude } \\
\text { (mean) }\end{array}$ & $\begin{array}{l}\text { divestiture } \\
\quad / \text { total } \\
\text { (funds) }\end{array}$ & $\begin{array}{l}\text { divestiture } \\
\text { /total } \\
\text { (cases) }\end{array}$ & $\begin{array}{c}\text { distressed } \\
\text { /total } \\
\text { (funds) }\end{array}$ & $\begin{array}{l}\text { distressed } \\
\quad / \text { total } \\
\text { (cases) }\end{array}$ & $\begin{array}{l}\text { investment } \\
\text { gov.asset/ } \\
\text { total funds }\end{array}$ & $\begin{array}{l}\text { water \& } \\
\text { sewerage } \\
\text { /utilities } \\
\text { (funds) }\end{array}$ & $\begin{array}{l}\text { water \& } \\
\text { sewerage } \\
\text { /utilities } \\
\text { (cases) }\end{array}$ & $\begin{array}{l}\text { electricity } \\
\text { /utilities } \\
\text { (funds) }\end{array}$ & $\begin{array}{l}\text { electricity } \\
\text { /utilities } \\
\text { (cases) }\end{array}$ \\
\hline \multirow[t]{3}{*}{ Argentina } & 1984-1998 & -0.24 & 0.52 & 0.42 & 0.43 & 0.23 & 0.25 & 0.09 & 0.05 & 0.35 & 0.57 \\
\hline & $1999-2000$ & -0.69 & 0.00 & 0.00 & 0.38 & 0.20 & 0.12 & 0.48 & 0.27 & 0.41 & 0.27 \\
\hline & $2001-2002$ & -1.14 & 0.00 & 0.00 & 0.00 & 0.00 & 0.19 & 0.00 & 0.00 & 0.00 & 0.00 \\
\hline \multirow[t]{3}{*}{ Bolivia } & 1984-1998 & 0.15 & 0.28 & 0.50 & 0.00 & 0.00 & 0.03 & 0.09 & 0.06 & 0.69 & 0.56 \\
\hline & $1999-2000$ & -0.33 & 0.02 & 0.14 & 0.48 & 0.14 & 0.04 & 0.48 & 0.14 & 0.27 & 0.57 \\
\hline & 2001-2002 & -0.62 & 0.00 & 0.00 & 0.00 & 0.00 & 0.00 & 0.00 & 0.00 & 0.74 & 0.33 \\
\hline \multirow[t]{3}{*}{ Brasil } & 1984-1998 & 0.08 & 0.72 & 0.28 & 0.05 & 0.05 & 0.43 & 0.02 & 0.14 & 0.30 & 0.27 \\
\hline & $1999-2000$ & -0.47 & 0.27 & 0.15 & 0.00 & 0.00 & 0.23 & 0.07 & 0.25 & 0.56 & 0.47 \\
\hline & $2001-2002$ & -0.35 & 0.01 & 0.02 & 0.03 & 0.02 & 0.17 & 0.00 & 0.09 & 0.48 & 0.72 \\
\hline \multirow[t]{3}{*}{ Chile } & 1984-1998 & 0.08 & 0.43 & 0.32 & 0.02 & 0.01 & 0.12 & 0.01 & 0.06 & 0.43 & 0.48 \\
\hline & $1999-2000$ & -0.37 & 0.72 & 0.36 & 0.00 & 0.00 & 0.32 & 0.72 & 0.36 & 0.18 & 0.14 \\
\hline & $2001-2002$ & -0.61 & 0.00 & 0.00 & 0.00 & 0.00 & 0.07 & 0.06 & 0.25 & 0.00 & 0.00 \\
\hline \multirow[t]{3}{*}{ Colombia } & 1984-1998 & -0.18 & 0.38 & 0.18 & 0.01 & 0.02 & 0.48 & 0.02 & 0.10 & 0.59 & 0.46 \\
\hline & $1999-2000$ & -0.51 & 0.03 & 0.10 & 0.12 & 0.10 & 0.07 & 0.04 & 0.20 & 0.19 & 0.30 \\
\hline & $2001-2002$ & -0.63 & 0.00 & 0.00 & 0.03 & 0.13 & 0.00 & 0.93 & 0.88 & 0.00 & 0.00 \\
\hline \multirow[t]{3}{*}{ Ecuador } & 1984-1998 & 0.18 & 0.00 & 0.00 & 0.00 & 0.10 & 0.07 & 0.00 & 0.00 & 0.02 & 0.20 \\
\hline & $1999-2000$ & -0.16 & 0.00 & 0.00 & 0.00 & 0.00 & 0.00 & 0.00 & 0.00 & 0.00 & 0.00 \\
\hline & $2001-2002$ & -0.10 & 0.00 & 0.00 & 0.00 & 0.00 & 0.00 & 1.00 & 1.00 & 0.00 & 0.00 \\
\hline \multirow[t]{3}{*}{ El salvador } & 1984-1998 & 0.15 & 0.86 & 0.58 & 0.00 & 0.00 & 0.63 & 0.00 & 0.00 & 0.37 & 0.50 \\
\hline & $1999-2000$ & -0.23 & 0.73 & 0.67 & 0.00 & 0.00 & 0.45 & 0.00 & 0.00 & 1.00 & 1.00 \\
\hline & $2001-2002$ & -0.20 & 0.00 & 0.00 & 0.00 & 0.00 & 0.00 & 0.00 & 0.00 & 0.00 & 0.00 \\
\hline \multirow[t]{3}{*}{ Guatemala } & 1984-1998 & 0.36 & 0.70 & 0.18 & 0.00 & 0.00 & 0.54 & 0.00 & 0.00 & 0.43 & 0.76 \\
\hline & $1999-2000$ & -0.49 & 0.22 & 0.20 & 0.00 & 0.00 & 0.36 & 0.00 & 0.00 & 0.41 & 0.60 \\
\hline & $2001-2002$ & -0.58 & 0.00 & 0.00 & 0.00 & 0.00 & 0.00 & 0.00 & 0.00 & 1.00 & 1.00 \\
\hline \multirow[t]{3}{*}{ Honduras } & 1984-1998 & 0.17 & 0.00 & 0.00 & 0.00 & 0.00 & 0.01 & 0.00 & 0.00 & 0.82 & 0.75 \\
\hline & $1999-2000$ & -0.05 & 0.00 & 0.00 & 0.00 & 0.00 & 0.00 & 0.00 & 0.00 & 0.00 & 0.00 \\
\hline & $2001-2002$ & -0.26 & 0.00 & 0.00 & 0.00 & 0.00 & 0.00 & 1.00 & 1.00 & 0.00 & 0.00 \\
\hline \multirow[t]{3}{*}{ México } & 1984-1998 & 0.13 & 0.52 & 0.05 & 0.14 & 0.16 & 0.20 & 0.01 & 0.14 & 0.04 & 0.20 \\
\hline & $1999-2000$ & -0.32 & 0.04 & 0.12 & 0.02 & 0.04 & 0.23 & 0.04 & 0.19 & 0.62 & 0.50 \\
\hline & $2001-2002$ & -0.59 & 0.00 & 0.00 & 0.00 & 0.00 & 0.00 & 0.01 & 0.14 & 0.35 & 0.71 \\
\hline \multirow[t]{3}{*}{ Panamá } & 1984-1998 & -0.94 & 0.52 & 0.31 & 0.00 & 0.00 & 0.45 & 0.01 & 0.08 & 0.15 & 0.31 \\
\hline & $1999-2000$ & -0.74 & 0.86 & 0.67 & 0.00 & 0.00 & 0.30 & 0.00 & 0.00 & 1.00 & 1.00 \\
\hline & $2001-2002$ & -0.41 & 0.00 & 0.00 & 0.00 & 0.00 & 0.00 & 0.00 & 0.00 & 0.00 & 0.00 \\
\hline \multirow[t]{3}{*}{ Paraguay } & 1984-1998 & 0.12 & 0.00 & 0.00 & 0.00 & 0.00 & 0.14 & 0.00 & 0.00 & 0.00 & 0.00 \\
\hline & $1999-2000$ & -0.30 & 0.00 & 0.00 & 0.00 & 0.00 & 0.00 & 0.00 & 0.00 & 0.00 & 0.00 \\
\hline & $2001-2002$ & -0.80 & 0.00 & 0.00 & 0.00 & 0.00 & 0.00 & 0.00 & 0.00 & 0.00 & 0.00 \\
\hline \multirow[t]{3}{*}{ Perú } & 1984-1998 & -0.08 & 0.84 & 0.60 & 0.05 & 0.20 & 0.41 & 0.00 & 0.00 & 0.34 & 0.76 \\
\hline & $1999-2000$ & -0.28 & 0.00 & 0.00 & 0.00 & 0.00 & 0.20 & 0.00 & 0.00 & 0.07 & 0.14 \\
\hline & $2001-2002$ & -0.32 & 0.75 & 0.43 & 0.00 & 0.00 & 0.29 & 0.06 & 0.14 & 0.56 & 0.43 \\
\hline \multirow[t]{3}{*}{ Uruguay } & $1984-1998$ & -0.41 & 0.00 & 0.00 & 0.00 & 0.00 & 0.00 & 0.03 & 0.17 & 0.27 & 0.17 \\
\hline & $1999-2000$ & -0.55 & 0.00 & 0.00 & 0.00 & 0.00 & 0.22 & 0.52 & 0.33 & 0.48 & 0.67 \\
\hline & 2001-2002 & -0.88 & 0.00 & 0.00 & 0.00 & 0.00 & 0.23 & 0.00 & 0.00 & 0.00 & 0.00 \\
\hline \multirow[t]{3}{*}{ Venezuela } & 1984-1998 & 0.23 & 0.76 & 0.27 & 0.01 & 0.09 & 0.28 & 0.00 & 0.09 & 0.01 & 0.18 \\
\hline & $1999-2000$ & 0.32 & 0.00 & 0.00 & 0.00 & 0.00 & 0.00 & 1.00 & 1.00 & 0.00 & 0.00 \\
\hline & $2001-2002$ & -0.19 & 0.00 & 0.00 & 0.00 & 0.00 & 0.00 & 0.08 & 0.50 & 0.00 & 0.00 \\
\hline \multirow[t]{3}{*}{ Total } & $1984-1998$ & 0.00 & 0.45 & 0.24 & 0.05 & 0.06 & 0.27 & 0.02 & 0.06 & 0.32 & 0.41 \\
\hline & $1999-2000$ & -0.31 & 0.19 & 0.16 & 0.07 & 0.03 & 0.17 & 0.25 & 0.20 & 0.35 & 0.38 \\
\hline & $2001-2002$ & -0.50 & 0.06 & 0.03 & 0.00 & 0.01 & 0.07 & 0.22 & 0.28 & 0.21 & 0.21 \\
\hline
\end{tabular}


Table 11 - Determinants of support for privatization - Latin America 1998-2000-2002 Privatisation features from FEEM, PrivatizationBarometer, Securities Data Corp.

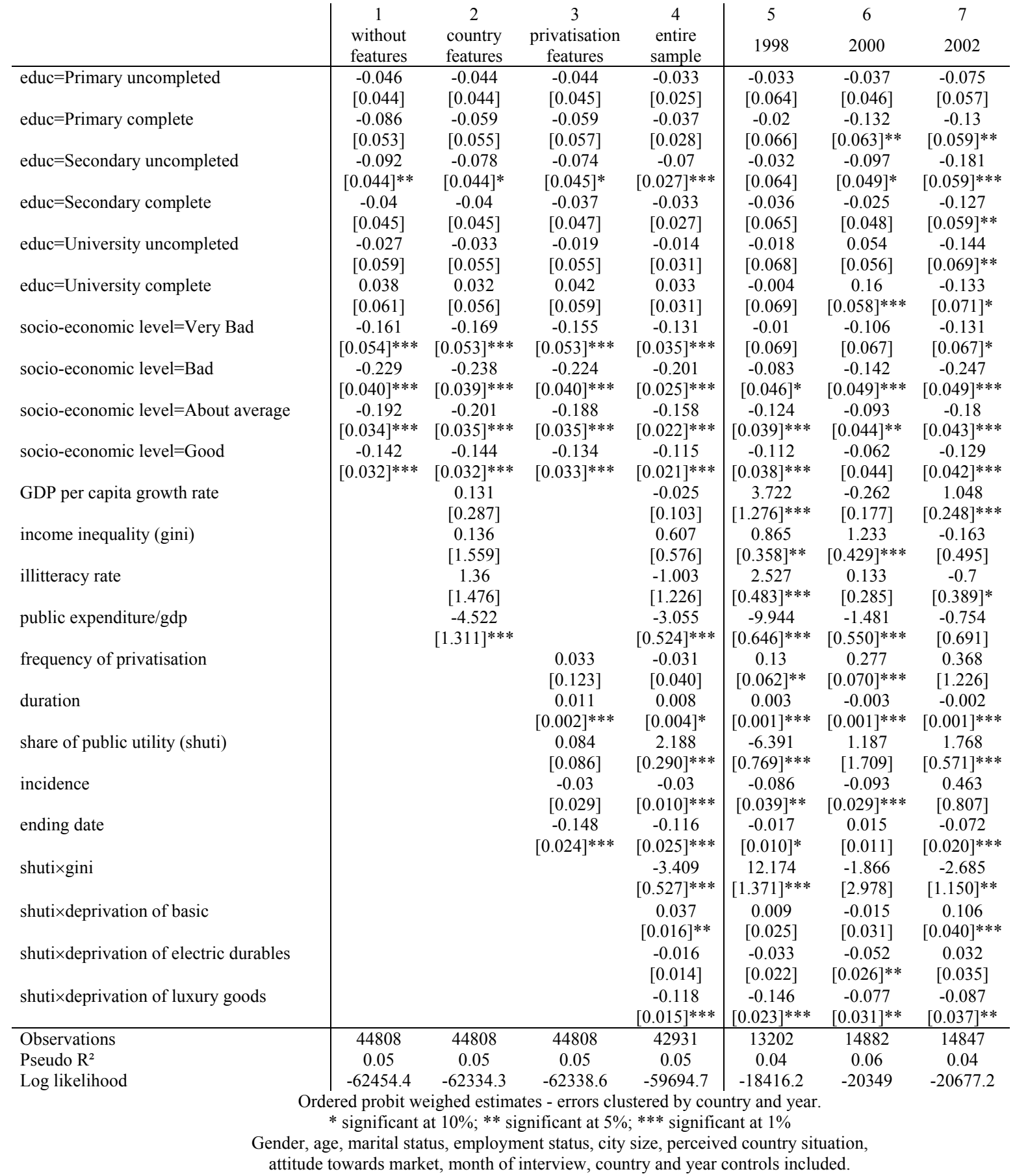


Table 12 - Determinants of support for privatization - Latin America 1998-2000-2002 Privatisation features from Private Participation in Infrastructure Database, The World Bank Group

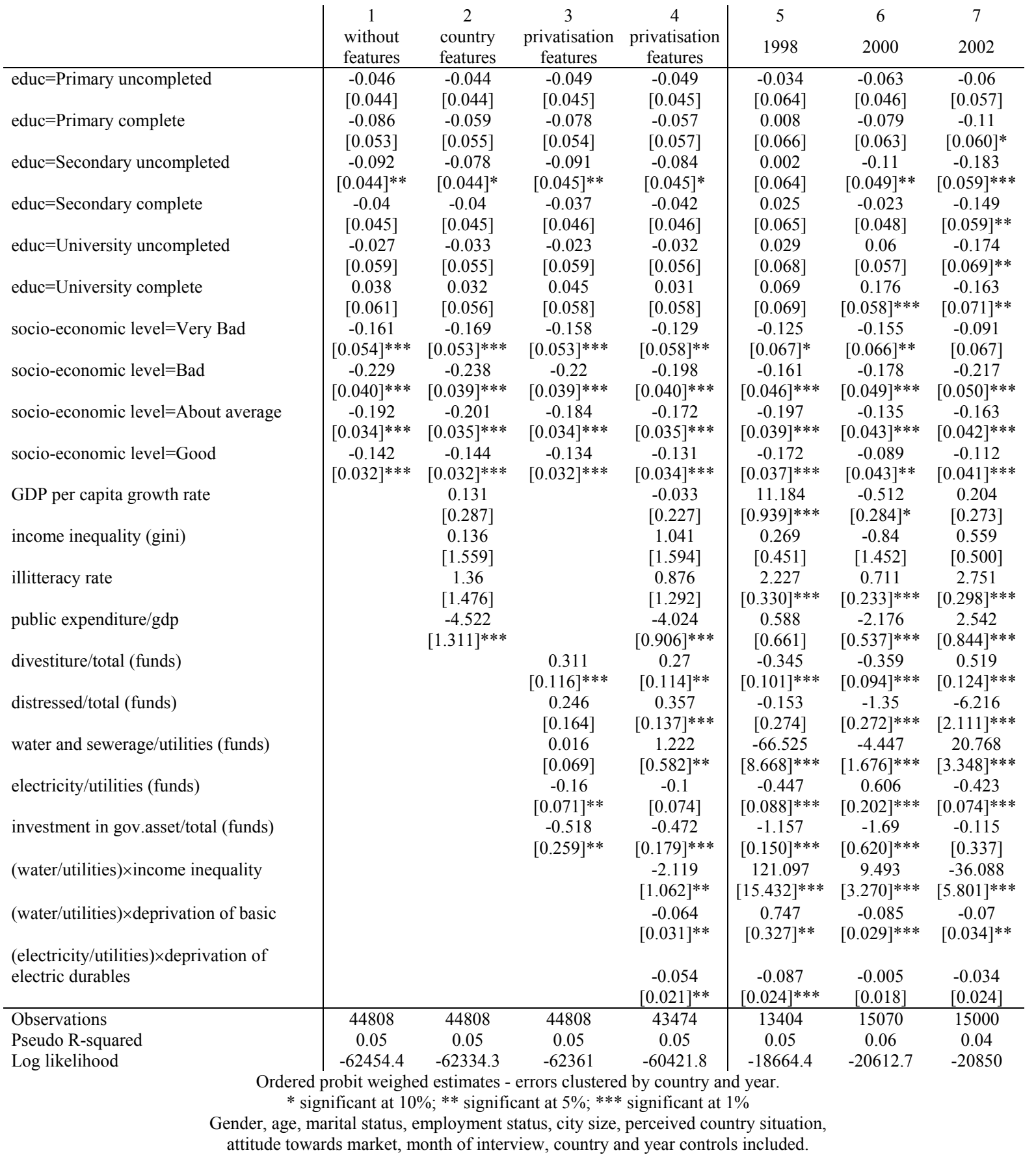


Appendix - Additional tables

Table A.1 - Latinobarometro - Probability of non responding

\begin{tabular}{|c|c|c|c|c|}
\hline & entire sample & 1998 & 2000 & 2002 \\
\hline \multirow[t]{2}{*}{ female } & 0.005 & 0.004 & 0.002 & 0.007 \\
\hline & {$[0.002]^{* *}$} & {$[0.003]$} & {$[0.001]^{*}$} & {$[0.003]^{* *}$} \\
\hline \multirow[t]{2}{*}{ age } & 0 & 0 & 0 & 0 \\
\hline & {$[0.000]$} & {$[0.000]$} & {$[0.000]$} & {$[0.000]$} \\
\hline \multirow[t]{2}{*}{ age squared } & 0 & 0 & 0 & 0 \\
\hline & {$[0.000]$} & {$[0.000]$} & {$[0.000]$} & {$[0.000]$} \\
\hline \multirow[t]{2}{*}{ chief income earner } & 0 & -0.001 & 0 & 0.001 \\
\hline & {$[0.002]$} & {$[0.003]$} & {$[0.002]$} & [0.002] \\
\hline \multirow[t]{2}{*}{ status $=$ Single } & 0 & -0.003 & 0.002 & -0.002 \\
\hline & {$[0.001]$} & {$[0.003]$} & {$[0.001]^{* *}$} & {$[0.001]$} \\
\hline \multirow[t]{2}{*}{ status=Divorced/widow/widower } & 0.001 & 0.002 & 0.002 & -0.002 \\
\hline & {$[0.002]$} & {$[0.003]$} & {$[0.002]$} & {$[0.004]$} \\
\hline \multirow[t]{2}{*}{ educ $=$ Primary uncompleted } & -0.005 & -0.003 & -0.001 & -0.008 \\
\hline & {$[0.002]^{* *}$} & {$[0.005]$} & {$[0.002]$} & {$[0.003]^{* *}$} \\
\hline \multirow[t]{2}{*}{ educ $=$ Primary complete } & -0.005 & -0.003 & -0.003 & -0.005 \\
\hline & {$[0.003]^{* *}$} & {$[0.004]$} & {$[0.002]$} & {$[0.004]$} \\
\hline \multirow[t]{2}{*}{ educ $=$ Secondary uncompleted } & -0.009 & -0.008 & -0.003 & -0.01 \\
\hline & {$[0.002]^{* * *}$} & {$[0.005]^{*}$} & {$[0.002]^{* *}$} & {$[0.003]^{* * *}$} \\
\hline \multirow[t]{2}{*}{ educ $=$ Secondary complete } & -0.012 & -0.008 & -0.005 & -0.013 \\
\hline & {$[0.002]^{* * *}$} & {$[0.004]^{*}$} & {$[0.002]^{* * *}$} & {$[0.002]^{* * *}$} \\
\hline educ $=$ University uncompleted & -0.01 & -0.012 & -0.003 & -0.01 \\
\hline & {$[0.002]^{* * *}$} & {$[0.003]^{* * *}$} & {$[0.002]^{* *}$} & {$[0.004]^{* * *}$} \\
\hline educ $=$ University complete & -0.011 & -0.012 & -0.002 & -0.015 \\
\hline & {$[0.001]^{* * *}$} & {$[0.003]^{* * *}$} & {$[0.002]$} & {$[0.002]^{* * *}$} \\
\hline condition $=$ selfemployed & -0.004 & -0.005 & -0.001 & -0.007 \\
\hline & {$[0.002]$} & {$[0.003]^{*}$} & {$[0.001]$} & {$[0.004]^{*}$} \\
\hline condition=employed public sct & -0.007 & -0.008 & -0.001 & -0.01 \\
\hline & {$[0.002]^{* * *}$} & {$[0.003]^{* * *}$} & {$[0.001]$} & {$[0.003]^{* * *}$} \\
\hline condition $=$ employed private sct & -0.004 & -0.005 & 0 & -0.009 \\
\hline & {$[0.002]^{* *}$} & {$[0.002]^{* *}$} & {$[0.001]$} & {$[0.004]^{* *}$} \\
\hline condition=unemployed & -0.005 & -0.006 & 0.002 & -0.01 \\
\hline & {$[0.003]$} & {$[0.005]$} & {$[0.004]$} & {$[0.004]^{* *}$} \\
\hline condition $=$ retired & -0.001 & 0.002 & 0.001 & -0.006 \\
\hline & {$[0.003]$} & {$[0.006]$} & {$[0.003]$} & {$[0.005]$} \\
\hline condition $=$ housewife & -0.002 & -0.006 & 0.002 & -0.004 \\
\hline & {$[0.002]$} & {$[0.003]^{*}$} & {$[0.003]$} & {$[0.004]$} \\
\hline selevel=Very Bad & 0.024 & 0.025 & 0.008 & 0.035 \\
\hline & {$[0.008]^{* * *}$} & {$[0.020]$} & {$[0.007]$} & {$[0.010]^{* * *}$} \\
\hline selevel $=\mathrm{Bad}$ & 0.01 & 0.018 & 0.005 & 0.009 \\
\hline & {$[0.003]^{* * *}$} & {$[0.006]^{* * *}$} & {$[0.002]^{* *}$} & {$[0.007]$} \\
\hline selevel $=$ About average & 0.003 & 0.006 & 0.002 & 0.001 \\
\hline & {$[0.002]^{*}$} & {$[0.004]$} & {$[0.001]$} & {$[0.005]$} \\
\hline selevel=Good & 0 & -0.003 & 0.002 & 0 \\
\hline & {$[0.002]$} & {$[0.004]$} & {$[0.002]$} & {$[0.004]$} \\
\hline dislike economic questions & -0.002 & -0.001 & -0.004 & 0.004 \\
\hline & {$[0.002]$} & {$[0.003]$} & {$[0.001]^{* * *}$} & {$[0.008]$} \\
\hline difficulty economic questions & 0.007 & 0.02 & 0.006 & -0.002 \\
\hline & {$[0.005]$} & {$[0.011]^{*}$} & {$[0.002]^{* *}$} & {$[0.005]$} \\
\hline month=may & 0 & -0.014 & -0.004 & 0.002 \\
\hline & {$[0.003]$} & {$[0.004]^{* * *}$} & {$[0.002]$} & {$[0.003]$} \\
\hline living in metropolitan areas & 0.005 & 0.01 & -0.004 & 0.004 \\
\hline & {$[0.005]$} & {$[0.011]$} & {$[0.002]^{*}$} & {$[0.006]$} \\
\hline country $=$ argentina & -0.012 & 0.04 & -0.007 & -0.02 \\
\hline & {$[0.001] * * *$} & {$[0.008]^{* * *}$} & {$[0.000]^{* * *}$} & {$[0.001]^{* * *}$} \\
\hline country=bolivia & -0.007 & 0.109 & -0.006 & -0.016 \\
\hline & {$[0.001]^{* * *}$} & {$[0.020]^{* * *}$} & {$[0.000]^{* * *}$} & {$[0.001] * * *$} \\
\hline country=brasil & -0.006 & 0 & -0.005 & -0.011 \\
\hline & {$[0.001] * * *$} & {$[0.005]$} & {$[0.001]^{* * *}$} & {$[0.001]^{* * *}$} \\
\hline country $=$ colombia & 0.001 & 0.062 & -0.007 & 0 \\
\hline & [0.002] & {$[0.013] * * *$} & {$[0.000]^{* * *}$} & {$[0.002]$} \\
\hline country $=$ costa rica & 0.001 & 0.045 & -0.002 & -0.01 \\
\hline & {$[0.001]$} & {$[0.008]^{* * *}$} & {$[0.002]$} & {$[0.001]^{* * *}$} \\
\hline country $=$ chile & -0.014 & 0.001 & -0.006 & -0.017 \\
\hline & {$[0.001] * * *$} & {$[0.005]$} & {$[0.000]^{* * *}$} & {$[0.001]^{* * *}$} \\
\hline country=ecuador & 0 & 0.075 & -0.004 & -0.01 \\
\hline & {$[0.002]$} & {$[0.015] * * *$} & {$[0.001]^{* * *}$} & {$[0.001]^{* * *}$} \\
\hline country $=\mathrm{el}$ salvador & 0 & 0.005 & -0.006 & 0.003 \\
\hline & {$[0.002]$} & {$[0.004]$} & {$[0.000]^{* * *}$} & {$[0.006]$} \\
\hline country=guatemala & -0.005 & -0.002 & -0.003 & -0.011 \\
\hline & {$[0.001]^{* * *}$} & {$[0.003]$} & {$[0.002]^{*}$} & {$[0.001]^{* * *}$} \\
\hline country=honduras & -0.001 & 0.075 & -0.006 & -0.013 \\
\hline & {$[0.001]$} & {$[0.011]^{* * *}$} & {$[0.000]^{* * *}$} & {$[0.001]^{* * *}$} \\
\hline
\end{tabular}




\begin{tabular}{|c|c|c|c|c|}
\hline \multirow[t]{2}{*}{ country=méxico } & -0.012 & 0.01 & -0.006 & -0.02 \\
\hline & {$[0.001]^{* * *}$} & {$[0.003]^{* * *}$} & {$[0.000]^{* * *}$} & {$[0.001]^{* * *}$} \\
\hline \multirow[t]{2}{*}{ country $=$ nicaragua } & -0.008 & 0.015 & -0.006 & -0.013 \\
\hline & {$[0.001]^{* * *}$} & {$[0.005]^{* * *}$} & {$[0.000]^{* * *}$} & {$[0.001]^{* * *}$} \\
\hline \multirow[t]{2}{*}{ country=panamá } & -0.008 & -0.01 & -0.006 & -0.009 \\
\hline & {$[0.000]^{* * *}$} & {$[0.002]^{* * *}$} & {$[0.000]^{* * *}$} & {$[0.002]^{* * *}$} \\
\hline \multirow[t]{2}{*}{ country=paraguay } & -0.009 & & & -0.019 \\
\hline & {$[0.001]^{* * *}$} & & & {$[0.001]^{* * *}$} \\
\hline \multirow[t]{2}{*}{ country=perú } & -0.003 & 0.062 & -0.005 & -0.009 \\
\hline & {$[0.001]^{* * *}$} & {$[0.016]^{* * *}$} & {$[0.001]^{* * *}$} & {$[0.002]^{* * *}$} \\
\hline \multirow[t]{2}{*}{ country=uruguay } & -0.006 & 0.05 & -0.006 & -0.011 \\
\hline & {$[0.001]^{* * *}$} & {$[0.012]^{* * *}$} & {$[0.000]^{* * *}$} & {$[0.001]^{* * *}$} \\
\hline Observations & 52634 & 16397 & 17278 & 18357 \\
\hline Pseudo $\mathrm{R}^{2}$ & 0.07 & 0.08 & 0.11 & 0.1 \\
\hline Log likelihood & -4830.71 & -1681.7 & -846.9 & -2093.04 \\
\hline
\end{tabular}


Table A.2 - Latinobarometro - Self-assessed socio-economic level - Percent distribution

\begin{tabular}{|c|c|c|c|c|c|c|}
\hline Country & & Very Bad & $\mathrm{Bad}$ & About average & Good & Very Good \\
\hline \multirow[t]{3}{*}{ Argentina } & 1998 & 0.85 & 7.51 & 36.31 & 45.16 & 10.17 \\
\hline & 2000 & 1.04 & 9.41 & 42.41 & 39.43 & 7.71 \\
\hline & 2002 & 1.07 & 7.87 & 35.15 & 42.57 & 13.35 \\
\hline \multirow[t]{3}{*}{ Bolivia } & 1998 & 0.56 & 11.87 & 45.54 & 34.57 & 7.47 \\
\hline & 2000 & 0.37 & 18.40 & 52.42 & 27.14 & 1.67 \\
\hline & 2002 & 3.43 & 29.91 & 50.24 & 15.17 & 1.25 \\
\hline \multirow[t]{3}{*}{ Brasil } & 1998 & 1.51 & 9.41 & 42.25 & 36.80 & 10.03 \\
\hline & 2000 & 0.63 & 10.41 & 39.81 & 37.58 & 11.58 \\
\hline & 2002 & 1.95 & 12.50 & 38.42 & 40.47 & 6.66 \\
\hline \multirow[t]{3}{*}{ Chile } & 1998 & 1.73 & 12.13 & 49.43 & 29.47 & 7.23 \\
\hline & 2000 & 3.35 & 19.36 & 51.62 & 23.09 & 2.58 \\
\hline & 2002 & 4.18 & 20.81 & 45.16 & 26.30 & 3.54 \\
\hline \multirow[t]{3}{*}{ Colombia } & 1998 & 0.77 & 6.58 & 35.98 & 46.41 & 10.26 \\
\hline & 2000 & 2.15 & 10.52 & 25.69 & 40.67 & 20.97 \\
\hline & 2002 & 3.80 & 11.87 & 30.55 & 42.11 & 11.67 \\
\hline \multirow[t]{3}{*}{ Costarica } & 1998 & 0.62 & 3.30 & 29.62 & 56.97 & 9.49 \\
\hline & 2000 & 1.05 & 4.63 & 37.64 & 39.22 & 17.46 \\
\hline & 2002 & 2.15 & 8.99 & 33.30 & 45.97 & 9.60 \\
\hline \multirow[t]{3}{*}{ Ecuador } & 1998 & 2.95 & 13.89 & 40.80 & 37.15 & 5.21 \\
\hline & 2000 & 1.35 & 11.76 & 38.58 & 44.25 & 4.06 \\
\hline & 2002 & 0.73 & 20.81 & 49.20 & 24.21 & 5.04 \\
\hline \multirow[t]{3}{*}{ El salvador } & 1998 & 1.82 & 5.76 & 30.10 & 42.93 & 19.39 \\
\hline & 2000 & 11.35 & 22.09 & 36.85 & 21.59 & 8.13 \\
\hline & 2002 & 9.90 & 23.94 & 29.47 & 28.33 & 8.35 \\
\hline \multirow[t]{3}{*}{ Guatemala } & 1998 & 15.89 & 35.53 & 24.09 & 15.99 & 8.50 \\
\hline & 2000 & 12.86 & 24.38 & 36.62 & 14.83 & 11.31 \\
\hline & 2002 & 3.24 & 13.96 & 40.86 & 33.74 & 8.20 \\
\hline \multirow[t]{3}{*}{ Honduras } & 1998 & 2.04 & 13.43 & 32.01 & 41.14 & 11.39 \\
\hline & 2000 & 11.30 & 25.13 & 33.20 & 20.28 & 10.09 \\
\hline & 2002 & 4.35 & 16.78 & 35.60 & 30.84 & 12.43 \\
\hline \multirow[t]{3}{*}{ México } & 1998 & 2.98 & 19.57 & 50.47 & 23.74 & 3.23 \\
\hline & 2000 & 6.54 & 27.71 & 50.17 & 14.03 & 1.55 \\
\hline & 2002 & 13.74 & 22.98 & 22.38 & 23.81 & 17.08 \\
\hline \multirow[t]{3}{*}{ Nicaragua } & 1998 & 2.24 & 11.72 & 47.91 & 27.62 & 10.50 \\
\hline & 2000 & 2.21 & 15.45 & 43.13 & 33.70 & 5.52 \\
\hline & 2002 & 12.20 & 25.81 & 32.16 & 21.17 & 8.67 \\
\hline \multirow[t]{3}{*}{ Panamá } & 1998 & 0.45 & 8.94 & 43.02 & 41.34 & 6.26 \\
\hline & 2000 & 0.61 & 6.37 & 41.46 & 40.44 & 11.12 \\
\hline & 2002 & 4.11 & 16.65 & 39.67 & 30.11 & 9.46 \\
\hline \multirow[t]{3}{*}{ Paraguay } & 1998 & 2.52 & 10.12 & 36.10 & 38.59 & 12.65 \\
\hline & 2000 & 1.32 & 12.28 & 38.33 & 38.39 & 9.67 \\
\hline & 2002 & 6.36 & 18.76 & 41.34 & 28.15 & 5.39 \\
\hline \multirow[t]{3}{*}{ Perú } & 1998 & 5.16 & 17.36 & 48.12 & 24.11 & 5.26 \\
\hline & 2000 & 1.63 & 20.38 & 50.58 & 25.38 & 2.02 \\
\hline & 2002 & 3.99 & 27.49 & 50.62 & 16.18 & 1.72 \\
\hline \multirow[t]{3}{*}{ Uruguay } & 1998 & 2.68 & 8.96 & 42.09 & 41.78 & 4.49 \\
\hline & 2000 & 2.49 & 8.85 & 42.05 & 42.92 & 3.69 \\
\hline & 2002 & 2.19 & 13.94 & 47.77 & 33.17 & 2.92 \\
\hline \multirow[t]{3}{*}{ Venezuela } & 1998 & 5.49 & 8.02 & 47.04 & 31.42 & 8.02 \\
\hline & 2000 & 0.26 & 6.15 & 52.09 & 33.05 & 8.45 \\
\hline & 2002 & 2.26 & 13.73 & 46.29 & 32.37 & 5.34 \\
\hline \multirow[t]{3}{*}{ Total } & 1998 & 3.00 & 11.99 & 40.28 & 36.13 & 8.61 \\
\hline & 2000 & 3.50 & 14.87 & 42.15 & 31.56 & 7.92 \\
\hline & 2002 & 4.59 & 18.16 & 39.53 & 30.07 & 7.66 \\
\hline
\end{tabular}


Table A.3 - Determinants of the socio-economic self-assessment. Weighed OLS with heteroskedasticity robust standard errors in parentheses

\begin{tabular}{|c|c|c|c|c|c|c|c|c|}
\hline & entire sample & 1998 & 2000 & 2002 & entire sample & 1998 & 2000 & 2002 \\
\hline \multirow[t]{2}{*}{ Has color TV } & -0.288 & -0.29 & -0.328 & -0.274 & -0.248 & -0.257 & -0.288 & -0.231 \\
\hline & {$[0.027]^{* * *}$} & {$[0.046]^{* * *}$} & {$[0.046]^{* * *}$} & {$[0.047]^{* * *}$} & {$[0.026]^{* * *}$} & {$[0.044]^{* * *}$} & {$[0.044]^{* * *}$} & {$[0.044] * * *$} \\
\hline \multirow[t]{2}{*}{ Has freezer } & -0.225 & -0.212 & -0.274 & -0.228 & -0.193 & -0.172 & -0.245 & -0.198 \\
\hline & {$[0.025]^{* * *}$} & {$[0.047]^{* * *}$} & {$[0.039]^{* * *}$} & {$[0.044]^{* * *}$} & {$[0.024]^{* * *}$} & {$[0.045]^{* * *}$} & {$[0.036]^{* * *}$} & {$[0.042]^{* * *}$} \\
\hline \multirow[t]{2}{*}{ Has house of your own } & -0.088 & -0.095 & -0.077 & -0.051 & -0.088 & -0.089 & -0.076 & -0.059 \\
\hline & {$[0.017]^{* * *}$} & {$[0.023]^{* * *}$} & {$[0.035]^{* *}$} & {$[0.025]^{*}$} & {$[0.017]^{* * *}$} & {$[0.023]^{* * *}$} & {$[0.034]^{* *}$} & {$[0.026]^{* *}$} \\
\hline \multirow[t]{2}{*}{ Has computer } & -0.28 & -0.244 & -0.252 & -0.369 & -0.218 & -0.181 & -0.185 & -0.311 \\
\hline & {$[0.040]^{* * *}$} & {$[0.034]^{* * *}$} & {$[0.029]^{* * *}$} & {$[0.116]^{* * *}$} & {$[0.046]^{* * *}$} & {$[0.033]^{* * *}$} & {$[0.028]^{* * *}$} & {$[0.133]^{* *}$} \\
\hline \multirow[t]{2}{*}{ Has washing machine } & -0.176 & -0.177 & -0.168 & -0.232 & -0.154 & -0.155 & -0.147 & -0.205 \\
\hline & {$[0.022]^{* * *}$} & {$[0.026]^{* * *}$} & {$[0.041]^{* * *}$} & {$[0.042]^{* * *}$} & {$[0.021]^{* * *}$} & {$[0.022]^{* * *}$} & {$[0.038]^{* * *}$} & {$[0.041]^{* * *}$} \\
\hline \multirow[t]{2}{*}{ Has telephone } & -0.251 & -0.279 & -0.261 & -0.242 & -0.213 & -0.245 & -0.219 & -0.203 \\
\hline & {$[0.019]^{* * *}$} & {$[0.031]^{* * *}$} & {$[0.022]^{* * *}$} & {$[0.028]^{* * *}$} & {$[0.017]^{* * *}$} & {$[0.031]^{* * *}$} & {$[0.019]^{* * *}$} & {$[0.024]^{* * *}$} \\
\hline \multirow[t]{2}{*}{ Has car } & -0.222 & -0.219 & -0.201 & -0.263 & -0.199 & -0.201 & -0.176 & -0.241 \\
\hline & {$[0.015]^{* * *}$} & {$[0.030]^{* * *}$} & {$[0.026]^{* * *}$} & {$[0.023]^{* * *}$} & {$[0.017]^{* * *}$} & {$[0.031]^{* * *}$} & {$[0.024]^{* * *}$} & {$[0.030]^{* * *}$} \\
\hline \multirow[t]{2}{*}{ Has a second house or holiday home } & -0.129 & -0.177 & -0.097 & -0.076 & -0.114 & -0.164 & -0.08 & -0.063 \\
\hline & {$[0.021]^{* * *}$} & {$[0.029]^{* * *}$} & {$[0.027]^{* * *}$} & {$[0.046]$} & {$[0.021]^{* * *}$} & {$[0.030]^{* * *}$} & {$[0.027]^{* * *}$} & {$[0.042]$} \\
\hline \multirow[t]{2}{*}{ Has drinking water } & -0.105 & -0.109 & -0.123 & -0.116 & -0.087 & -0.098 & -0.105 & -0.091 \\
\hline & {$[0.029]^{* * *}$} & {$[0.037]^{* * *}$} & {$[0.055]^{* *}$} & {$[0.051]^{* *}$} & {$[0.030]^{* * *}$} & {$[0.040]^{* *}$} & {$[0.056]^{*}$} & {$[0.049]^{*}$} \\
\hline \multirow[t]{2}{*}{ Has hot water } & -0.116 & -0.154 & -0.113 & -0.107 & -0.098 & -0.144 & -0.092 & -0.084 \\
\hline & {$[0.025]^{* * *}$} & {$[0.032]^{* * *}$} & {$[0.032]^{* * *}$} & {$[0.059]^{*}$} & {$[0.024]^{* * *}$} & {$[0.033]^{* * *}$} & {$[0.030]^{* * *}$} & {$[0.054]$} \\
\hline \multirow[t]{2}{*}{ Has sewage system } & -0.127 & -0.103 & -0.082 & -0.199 & -0.102 & -0.075 & -0.06 & -0.176 \\
\hline & {$[0.027]^{* * *}$} & {$[0.040]^{* *}$} & {$[0.021]^{* * *}$} & {$[0.055]^{* * *}$} & {$[0.029]^{* * *}$} & {$[0.038]^{*}$} & {$[0.025]^{* *}$} & {$[0.057]^{* * *}$} \\
\hline \multirow[t]{2}{*}{ Public Insurance } & -0.177 & -0.162 & -0.178 & -0.183 & -0.164 & -0.153 & -0.163 & -0.16 \\
\hline & {$[0.018]^{* * *}$} & {$[0.026]^{* * *}$} & {$[0.033]^{* * *}$} & {$[0.031]^{* * *}$} & {$[0.015]^{* * *}$} & {$[0.021]^{* * *}$} & {$[0.028]^{* * *}$} & {$[0.022] * * *$} \\
\hline Don't have Insurance & -0.283 & -0.184 & -0.284 & -0.25 & -0.251 & -0.154 & -0.242 & -0.201 \\
\hline & {$[0.034]^{* * *}$} & {$[0.035]^{* * *}$} & {$[0.040]^{* * *}$} & {$[0.048]^{* * *}$} & {$[0.033]^{* * *}$} & {$[0.031]^{* * *}$} & {$[0.035]^{* * *}$} & {$[0.045]^{* * *}$} \\
\hline female & & & & & 0.035 & 0.023 & 0.044 & 0.034 \\
\hline & & & & & {$[0.008]^{* * *}$} & {$[0.018]$} & {$[0.014]^{* * *}$} & {$[0.013]^{* *}$} \\
\hline age & & & & & 0.007 & 0.003 & 0.006 & 0.009 \\
\hline & & & & & {$[0.002]^{* * *}$} & {$[0.003]$} & {$[0.002]^{* *}$} & {$[0.003]^{* * *}$} \\
\hline age squared & & & & & 0 & 0 & 0 & 0 \\
\hline & & & & & {$[0.000]^{* * *}$} & {$[0.000]$} & {$[0.000]$} & {$[0.000]^{* *}$} \\
\hline chief income earner & & & & & -0.045 & -0.035 & -0.044 & -0.044 \\
\hline & & & & & {$[0.011]^{* * *}$} & {$[0.015]^{* *}$} & {$[0.023]^{*}$} & {$[0.018]^{* *}$} \\
\hline educ $=$ Primary uncompleted & & & & & 0.14 & 0.09 & 0.113 & 0.157 \\
\hline & & & & & {$[0.036]^{* * *}$} & {$[0.048]^{*}$} & {$[0.038]^{* * *}$} & {$[0.068]^{* *}$} \\
\hline educ $=$ Primary complete & & & & & 0.211 & 0.163 & 0.168 & 0.253 \\
\hline & & & & & {$[0.036]^{* * *}$} & {$[0.045]^{* * *}$} & {$[0.042]^{* * *}$} & {$[0.067]^{* * *}$} \\
\hline educ $=$ Secondary uncompleted & & & & & 0.275 & 0.197 & 0.264 & 0.329 \\
\hline & & & & & {$[0.046]^{* * *}$} & {$[0.050]^{* * *}$} & {$[0.039]^{* * *}$} & {$[0.091]^{* * *}$} \\
\hline educ $=$ Secondary complete & & & & & 0.378 & 0.324 & 0.372 & 0.403 \\
\hline & & & & & {$[0.057]^{* * *}$} & {$[0.050]^{* * *}$} & {$[0.048]^{* * *}$} & {$[0.122]^{* * *}$} \\
\hline educ $=$ University uncompleted & & & & & 0.455 & 0.425 & 0.427 & 0.468 \\
\hline & & & & & {$[0.059]^{* * *}$} & {$[0.063]^{* * *}$} & {$[0.050]^{* * *}$} & {$[0.118]^{* * *}$} \\
\hline educ $=$ University complete & & & & & 0.559 & 0.489 & 0.577 & 0.617 \\
\hline & & & & & {$[0.060]^{* * *}$} & {$[0.049]^{* * *}$} & {$[0.066]^{* * *}$} & {$[0.123]^{* * *}$} \\
\hline condition $=$ selfemployed & & & & & -0.069 & -0.065 & -0.071 & -0.115 \\
\hline & & & & & {$[0.025]^{* * *}$} & {$[0.045]$} & {$[0.047]$} & {$[0.028]^{* * *}$} \\
\hline condition=employed public sct & & & & & -0.08 & -0.074 & -0.1 & -0.077 \\
\hline & & & & & {$[0.022]^{* * *}$} & {$[0.032]^{* *}$} & {$[0.045]^{* *}$} & {$[0.033]^{* *}$} \\
\hline condition $=$ employed private sct & & & & & -0.108 & -0.126 & -0.102 & -0.111 \\
\hline & & & & & {$[0.023]^{* * *}$} & {$[0.037]^{* * *}$} & {$[0.050]^{*}$} & {$[0.023]^{* * *}$} \\
\hline condition=unemployed & & & & & -0.15 & -0.19 & -0.154 & -0.166 \\
\hline & & & & & {$[0.032]^{* * *}$} & {$[0.034]^{* * *}$} & {$[0.061]^{* *}$} & {$[0.036] * * *$} \\
\hline condition=retired & & & & & -0.009 & 0.011 & -0.03 & -0.043 \\
\hline & & & & & {$[0.031]$} & {$[0.046]$} & {$[0.055]$} & {$[0.047]$} \\
\hline condition $=$ housewife & & & & & -0.112 & -0.099 & -0.118 & -0.136 \\
\hline & & & & & {$[0.022]^{* * *}$} & {$[0.032]^{* * *}$} & {$[0.037]^{* * *}$} & {$[0.033]^{* * *}$} \\
\hline Observations & 50190 & 15903 & 16812 & 17475 & 49379 & 15092 & 16812 & 17475 \\
\hline $\mathrm{R}^{2}$ & 0.32 & 0.35 & 0.35 & 0.33 & 0.34 & 0.37 & 0.37 & 0.35 \\
\hline
\end{tabular}


Table A.4- Descriptive statistics (mean and percentage) by country - Latin America 1998-20002002

\begin{tabular}{|c|c|c|c|c|c|c|c|}
\hline Country & & $\begin{array}{c}\text { attitude } \\
\text { towards } \\
\text { privatisation }\end{array}$ & female & age & $\begin{array}{c}\text { chief } \\
\text { income } \\
\text { earner }\end{array}$ & $\begin{array}{l}\text { years of } \\
\text { education }\end{array}$ & $\begin{array}{c}\text { socio- } \\
\text { economic } \\
\text { level } \\
\end{array}$ \\
\hline \multirow[t]{3}{*}{ Argentina } & 1998 & -0.22 & 0.52 & 42.53 & 0.50 & 10.08 & 0.56 \\
\hline & 2000 & -0.72 & 0.52 & 42.67 & 0.51 & 9.62 & 0.43 \\
\hline & 2002 & -1.15 & 0.52 & 42.37 & 0.47 & 10.08 & 0.59 \\
\hline \multirow[t]{3}{*}{ Bolivia } & 1998 & 0.10 & 0.57 & 38.06 & 0.53 & 7.93 & 0.37 \\
\hline & 2000 & -0.33 & 0.51 & 34.17 & 0.46 & 10.86 & 0.11 \\
\hline & 2002 & -0.59 & 0.52 & 41.56 & 0.57 & 6.92 & -0.19 \\
\hline \multirow[t]{3}{*}{ Brasil } & 1998 & 0.12 & 0.53 & 38.02 & 0.42 & 8.10 & 0.44 \\
\hline & 2000 & -0.50 & 0.53 & 38.52 & 0.47 & 8.32 & 0.49 \\
\hline & 2002 & -0.35 & 0.51 & 37.15 & 0.46 & 6.09 & 0.37 \\
\hline \multirow[t]{3}{*}{ Chile } & 1998 & 0.10 & 0.54 & 39.36 & 0.39 & 10.75 & 0.28 \\
\hline & 2000 & -0.42 & 0.52 & 40.01 & 0.44 & 9.13 & 0.02 \\
\hline & 2002 & -0.65 & 0.52 & 40.57 & 0.46 & 9.39 & 0.04 \\
\hline \multirow[t]{3}{*}{ Colombia } & 1998 & -0.18 & 0.50 & 37.65 & 0.53 & 9.77 & 0.59 \\
\hline & 2000 & -0.54 & 0.52 & 38.30 & 0.51 & 10.39 & 0.68 \\
\hline & 2002 & -0.65 & 0.53 & 35.85 & 0.47 & 6.98 & 0.46 \\
\hline \multirow[t]{3}{*}{ Costarica } & 1998 & 0.37 & 0.50 & 41.49 & 0.60 & 9.89 & 0.71 \\
\hline & 2000 & -0.08 & 0.50 & 38.86 & 0.54 & 8.98 & 0.67 \\
\hline & 2002 & -0.28 & 0.51 & 37.27 & 0.44 & 7.69 & 0.52 \\
\hline \multirow[t]{3}{*}{ Ecuador } & 1998 & 0.18 & 0.49 & 36.38 & 0.47 & 9.67 & 0.28 \\
\hline & 2000 & -0.16 & 0.50 & 36.59 & 0.47 & 9.84 & 0.38 \\
\hline & 2002 & -0.18 & 0.54 & 41.42 & 0.55 & 7.61 & 0.12 \\
\hline \multirow[t]{3}{*}{ El salvador } & 1998 & 0.15 & 0.51 & 34.25 & 0.70 & 10.85 & 0.72 \\
\hline & 2000 & -0.23 & 0.51 & 36.57 & 0.46 & 8.78 & -0.07 \\
\hline & 2002 & -0.19 & 0.52 & 38.69 & 0.55 & 6.74 & 0.01 \\
\hline \multirow[t]{3}{*}{ Guatemala } & 1998 & 0.36 & 0.49 & 33.35 & 0.47 & 10.75 & -0.34 \\
\hline & 2000 & -0.49 & 0.49 & 36.59 & 0.46 & 10.18 & -0.13 \\
\hline & 2002 & -0.59 & 0.52 & 37.11 & 0.45 & 7.65 & 0.30 \\
\hline \multirow[t]{3}{*}{ Honduras } & 1998 & 0.17 & 0.52 & 37.64 & 0.53 & 9.73 & 0.46 \\
\hline & 2000 & -0.05 & 0.51 & 37.32 & 0.48 & 9.61 & -0.07 \\
\hline & 2002 & -0.31 & 0.51 & 37.65 & 0.54 & 5.79 & 0.30 \\
\hline \multirow[t]{3}{*}{ México } & 1998 & 0.13 & 0.49 & 36.51 & 0.45 & 9.18 & 0.05 \\
\hline & 2000 & -0.32 & 0.51 & 37.07 & 0.48 & 8.59 & -0.24 \\
\hline & 2002 & -0.62 & 0.51 & 36.33 & 0.59 & 7.75 & 0.08 \\
\hline \multirow[t]{3}{*}{ Nicaragua } & 1998 & 0.04 & 0.51 & 36.42 & 0.61 & 11.32 & 0.32 \\
\hline & 2000 & -0.01 & 0.51 & 35.11 & 0.54 & 9.94 & 0.25 \\
\hline & 2002 & -0.41 & 0.50 & 34.57 & 0.43 & 6.93 & -0.12 \\
\hline \multirow[t]{3}{*}{ Panamá } & 1998 & -0.94 & 0.54 & 38.71 & 0.56 & 11.07 & 0.44 \\
\hline & 2000 & -0.74 & 0.49 & 39.34 & 0.58 & 11.34 & 0.55 \\
\hline & 2002 & -0.41 & 0.49 & 38.28 & 0.54 & 8.26 & 0.24 \\
\hline \multirow[t]{3}{*}{ Paraguay } & 1998 & 0.10 & 0.53 & 40.84 & 0.46 & 8.27 & 0.49 \\
\hline & 2000 & -0.32 & 0.52 & 41.31 & 0.47 & 9.75 & 0.43 \\
\hline & 2002 & -0.78 & 0.52 & 35.70 & 0.40 & 8.07 & 0.07 \\
\hline \multirow[t]{3}{*}{ Perú } & 1998 & -0.08 & 0.50 & 35.87 & 0.41 & 11.94 & 0.07 \\
\hline & 2000 & -0.28 & 0.50 & 35.24 & 0.43 & 12.25 & 0.06 \\
\hline & 2002 & -0.31 & 0.50 & 38.86 & 0.50 & 9.84 & -0.16 \\
\hline \multirow[t]{3}{*}{ Uruguay } & 1998 & -0.40 & 0.51 & 48.41 & 0.62 & 7.82 & 0.36 \\
\hline & 2000 & -0.59 & 0.51 & 46.58 & 0.58 & 7.89 & 0.36 \\
\hline & 2002 & -0.81 & 0.56 & 44.96 & 0.52 & 8.01 & 0.21 \\
\hline \multirow[t]{3}{*}{ Venezuela } & 1998 & 0.23 & 0.49 & 37.19 & 0.47 & 8.95 & 0.28 \\
\hline & 2000 & 0.32 & 0.50 & 37.04 & 0.49 & 9.26 & 0.43 \\
\hline & 2002 & -0.18 & 0.50 & 39.63 & 0.53 & 8.16 & 0.25 \\
\hline \multirow[t]{3}{*}{ Total } & 1998 & 0.00 & 0.51 & 38.45 & 0.51 & 9.81 & 0.35 \\
\hline & 2000 & -0.33 & 0.51 & 38.33 & 0.49 & 9.67 & 0.26 \\
\hline & 2002 & -0.50 & 0.52 & 38.91 & 0.50 & 7.81 & 0.18 \\
\hline
\end{tabular}


Table A.5 - Determinants of support for privatization - Latin America 1998-2000-2002

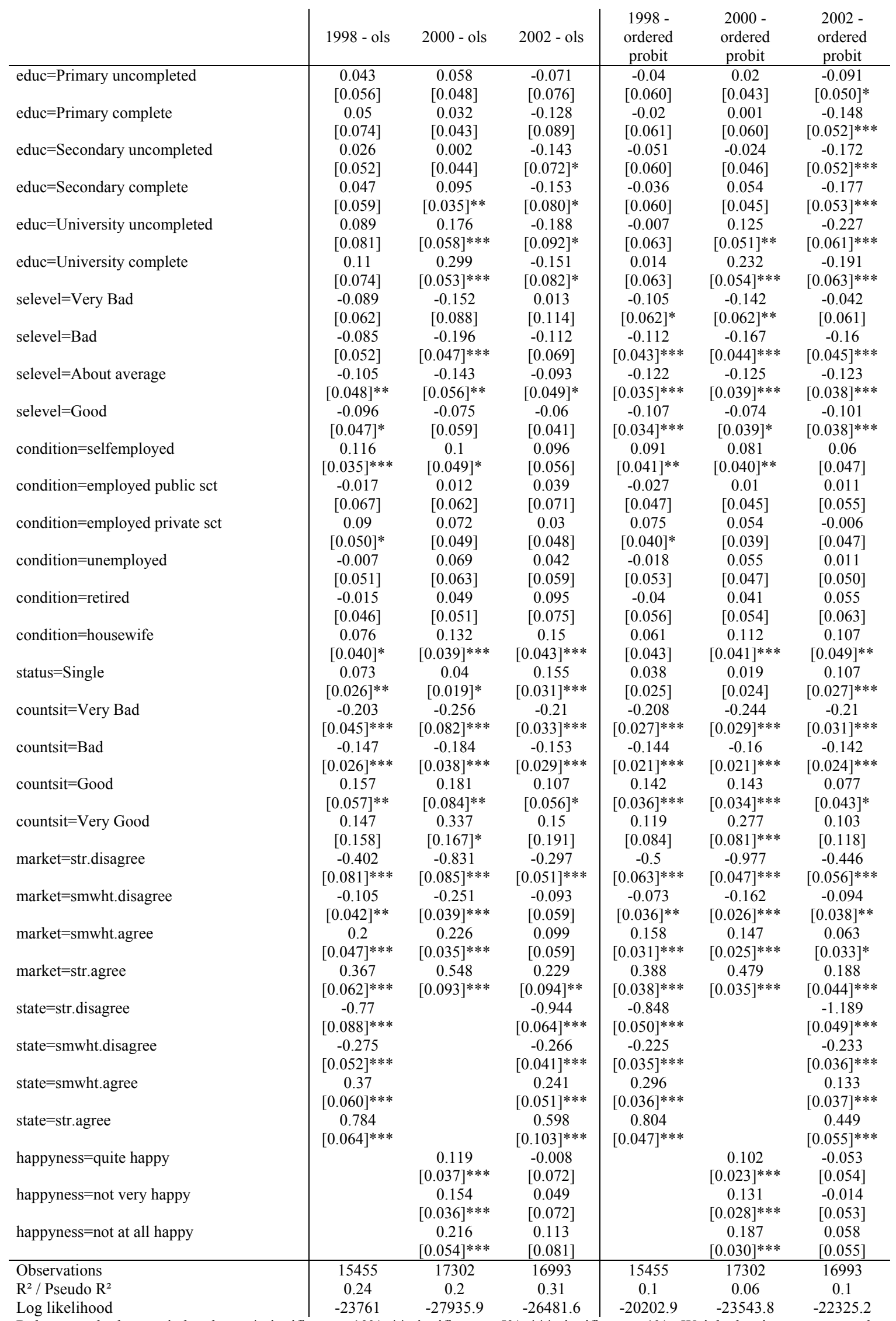

Robust standard errors in brackets - * significant at $10 \%$; * significant at $5 \%$; *** significant at $1 \%$ - Weighed estimates - errors clustered by country. - Age, age squared, gender, chief income earner, widowed/divorced, city size, month of interview, dislike and difficulties to understand, country controls included. 
Table A.6 - Effects of socio-economic condition on support to privatization by country - Latin America 1998-2000-2002

\begin{tabular}{|c|c|c|c|c|c|c|c|c|c|c|c|c|c|c|c|c|c|}
\hline & Argentina & Bolivia & Brasil & Colombia & $\begin{array}{l}\text { Costa } \\
\text { Rica }\end{array}$ & Chile & Ecuador & $\begin{array}{c}\text { El } \\
\text { Salvador } \\
\end{array}$ & Guatemala & Honduras & Mexico & Nicaragua & Panama & Paraguay & Peru & Uruguay & Venezuela \\
\hline selevel=Very Bad & $\begin{array}{c}0.351 \\
{[0.224]}\end{array}$ & $\begin{array}{c}0.106 \\
{[0.271]}\end{array}$ & $\begin{array}{c}0.108 \\
{[0.216]}\end{array}$ & $\begin{array}{c}-0.147 \\
{[0.171]}\end{array}$ & $\begin{array}{c}0.023 \\
{[0.178]}\end{array}$ & $\begin{array}{c}0.012 \\
{[0.214]}\end{array}$ & $\begin{array}{c}-0.24 \\
{[0.173]}\end{array}$ & $\begin{array}{c}-0.233 \\
{[0.114]^{* *}}\end{array}$ & $\begin{array}{c}-0.174 \\
{[0.098]^{*}}\end{array}$ & $\begin{array}{c}-0.315 \\
{[0.118]^{* * *}}\end{array}$ & $\begin{array}{c}-0.261 \\
{[0.117]^{* *}}\end{array}$ & $\begin{array}{c}-0.03 \\
{[0.135]}\end{array}$ & $\begin{array}{c}-0.18 \\
{[0.198]}\end{array}$ & $\begin{array}{c}-0.031 \\
{[0.178]}\end{array}$ & $\begin{array}{c}-0.6 \\
{[0.156]^{* * *}}\end{array}$ & $\begin{array}{c}-0.369 \\
{[0.196]^{*}}\end{array}$ & $\begin{array}{c}0.106 \\
{[0.271]}\end{array}$ \\
\hline selevel=Bad & 0.092 & -0.283 & -0.219 & -0.244 & 0.201 & -0.2 & -0.404 & -0.34 & -0.248 & -0.217 & -0.294 & -0.078 & -0.251 & -0.153 & -0.565 & -0.198 & -0.283 \\
\hline & {$[0.097]$} & {$[0.145]^{*}$} & {$[0.109]^{* *}$} & {$[0.102]^{* *}$} & {$[0.098]^{* *}$} & {$[0.109]^{*}$} & {$[0.104]^{* * *}$} & {$[0.095]^{* * *}$} & {$[0.087]^{* * *}$} & {$[0.090]^{* *}$} & {$[0.100]^{* * *}$} & {$[0.093]$} & {$[0.109]^{* *}$} & {$[0.143]$} & {$[0.116]^{* * *}$} & {$[0.134]$} & {$[0.145]^{*}$} \\
\hline selevel=About average & $\begin{array}{c}0.162 \\
{[0.073]^{* *}}\end{array}$ & $\begin{array}{c}-0.1 \\
{[0.135]}\end{array}$ & $\begin{array}{c}-0.218 \\
{[0.089]^{* *}}\end{array}$ & $\begin{array}{c}-0.279 \\
{[0.082]^{* * *}}\end{array}$ & $\begin{array}{c}-0.064 \\
{[0.076]}\end{array}$ & $\begin{array}{c}-0.251 \\
{[0.089]^{* * *}}\end{array}$ & $\begin{array}{c}-0.143 \\
{[0.083]^{*}}\end{array}$ & $\begin{array}{c}-0.391 \\
{[0.081]^{* * *}}\end{array}$ & $\begin{array}{c}-0.338 \\
{[0.086]^{* * *}}\end{array}$ & $\begin{array}{c}-0.283 \\
{[0.079]^{* * *}}\end{array}$ & $\begin{array}{c}-0.168 \\
{[0.096]^{*}}\end{array}$ & $\begin{array}{c}-0.139 \\
{[0.079]^{*}}\end{array}$ & $\begin{array}{c}-0.191 \\
{[0.081]^{* *}}\end{array}$ & $\begin{array}{c}-0.115 \\
{[0.109]}\end{array}$ & $\begin{array}{c}-0.564 \\
{[0.109] * * *}\end{array}$ & $\begin{array}{c}-0.314 \\
{[0.113]^{* * *}}\end{array}$ & $\begin{array}{c}-0.1 \\
{[0.135]}\end{array}$ \\
\hline selevel=Good & $\begin{array}{c}0.098 \\
{[0.071]} \\
\end{array}$ & $\begin{array}{c}0.035 \\
{[0.138]}\end{array}$ & $\begin{array}{c}-0.188 \\
{[0.085]^{* *}}\end{array}$ & $\begin{array}{c}-0.164 \\
{[0.078]^{* *}}\end{array}$ & $\begin{array}{c}-0.023 \\
{[0.072]}\end{array}$ & $\begin{array}{c}-0.164 \\
{[0.088]^{*}} \\
\end{array}$ & $\begin{array}{c}-0.064 \\
{[0.080]} \\
\end{array}$ & $\begin{array}{c}-0.366 \\
{[0.074]^{* * *}}\end{array}$ & $\begin{array}{c}-0.211 \\
{[0.088]^{* *}}\end{array}$ & $\begin{array}{c}-0.14 \\
{[0.077]^{*}}\end{array}$ & $\begin{array}{c}-0.1 \\
{[0.100]} \\
\end{array}$ & $\begin{array}{c}-0.231 \\
{[0.081]^{* * *}}\end{array}$ & $\begin{array}{c}-0.205 \\
{[0.080]^{* *}}\end{array}$ & $\begin{array}{c}-0.03 \\
{[0.106]}\end{array}$ & $\begin{array}{c}-0.374 \\
{[0.113]^{* * *}}\end{array}$ & $\begin{array}{c}-0.35 \\
{[0.111]^{* * *}}\end{array}$ & $\begin{array}{c}0.035 \\
{[0.138]}\end{array}$ \\
\hline Observatiol & 3423 & 2696 & 2835 & 3393 & 2614 & 3463 & 3336 & 2718 & 2745 & 2619 & 3417 & 2820 & 2680 & 1723 & 3030 & 3418 & 2696 \\
\hline Pseudo $\mathrm{R}^{2}$ & 0.07 & 0.05 & 0.04 & 0.03 & 0.05 & 0.07 & 0.06 & 0.08 & 0.05 & 0.04 & 0.04 & 0.04 & 0.07 & 0.07 & 0.04 & 0.09 & 0.05 \\
\hline
\end{tabular}

Ordered probit weighed estimates - Robust standard errors in brackets - * significant at 10\%; ** significant at 5\%; ** significant at 1\% Gender, age, years of education (level and squared), economic condition, marital status city size, erceived country situation, attitude towards market, month of interview, and year controls included 
Figure 1 - Estimates of the impact of education and socio-economic level on support to privatization - Latin America 1998-2000-2002

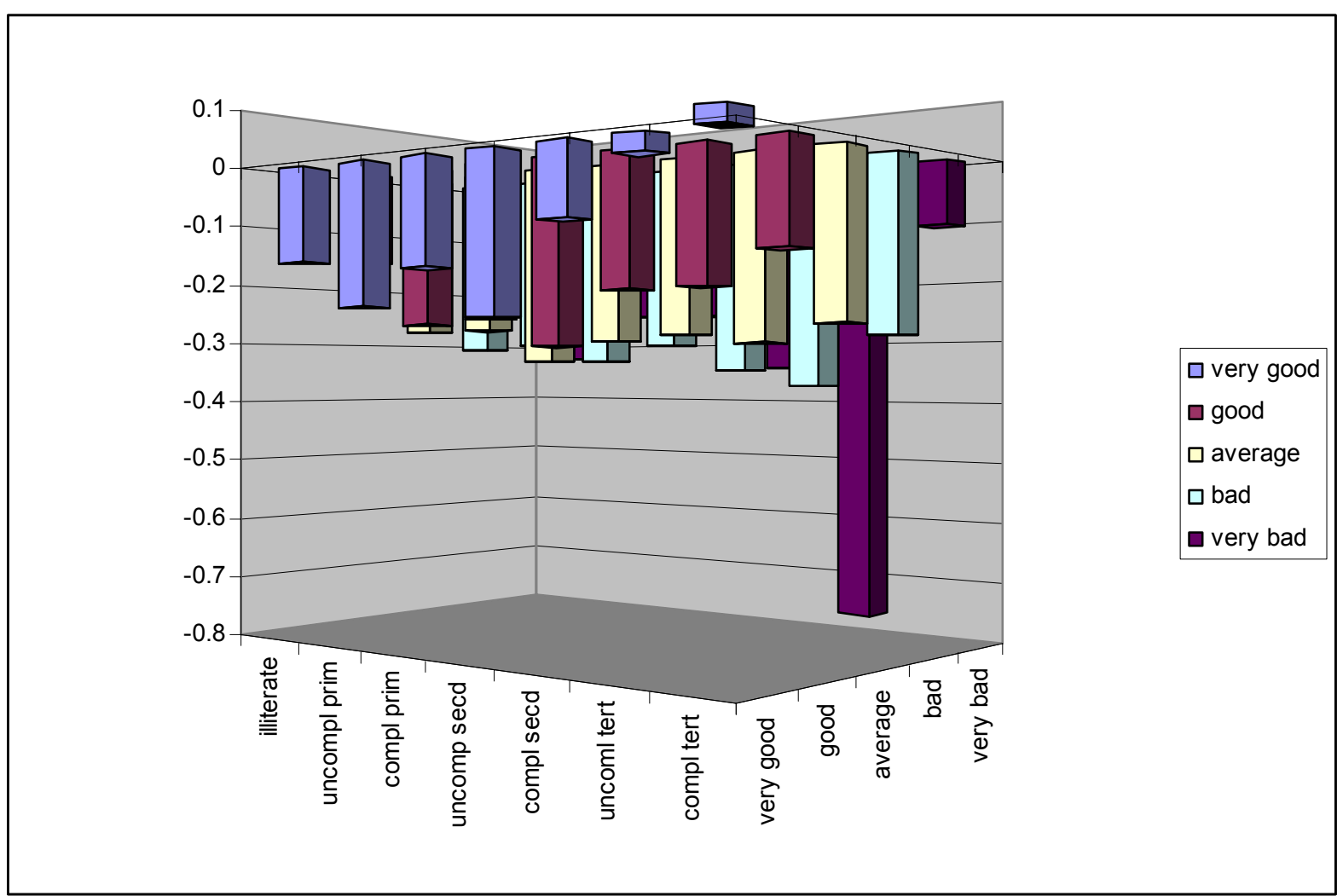

Note: probit weighed regression, including gender, age, age ${ }^{2}$, marital status, employment conditions, opinions about the country situation and the effectiveness of the market, city size, month of interview, country and year dummies. 
Figure 2 - Estimates of the impact of education and ownership of durables on support to privatization - Latin America 1998-2000-2002

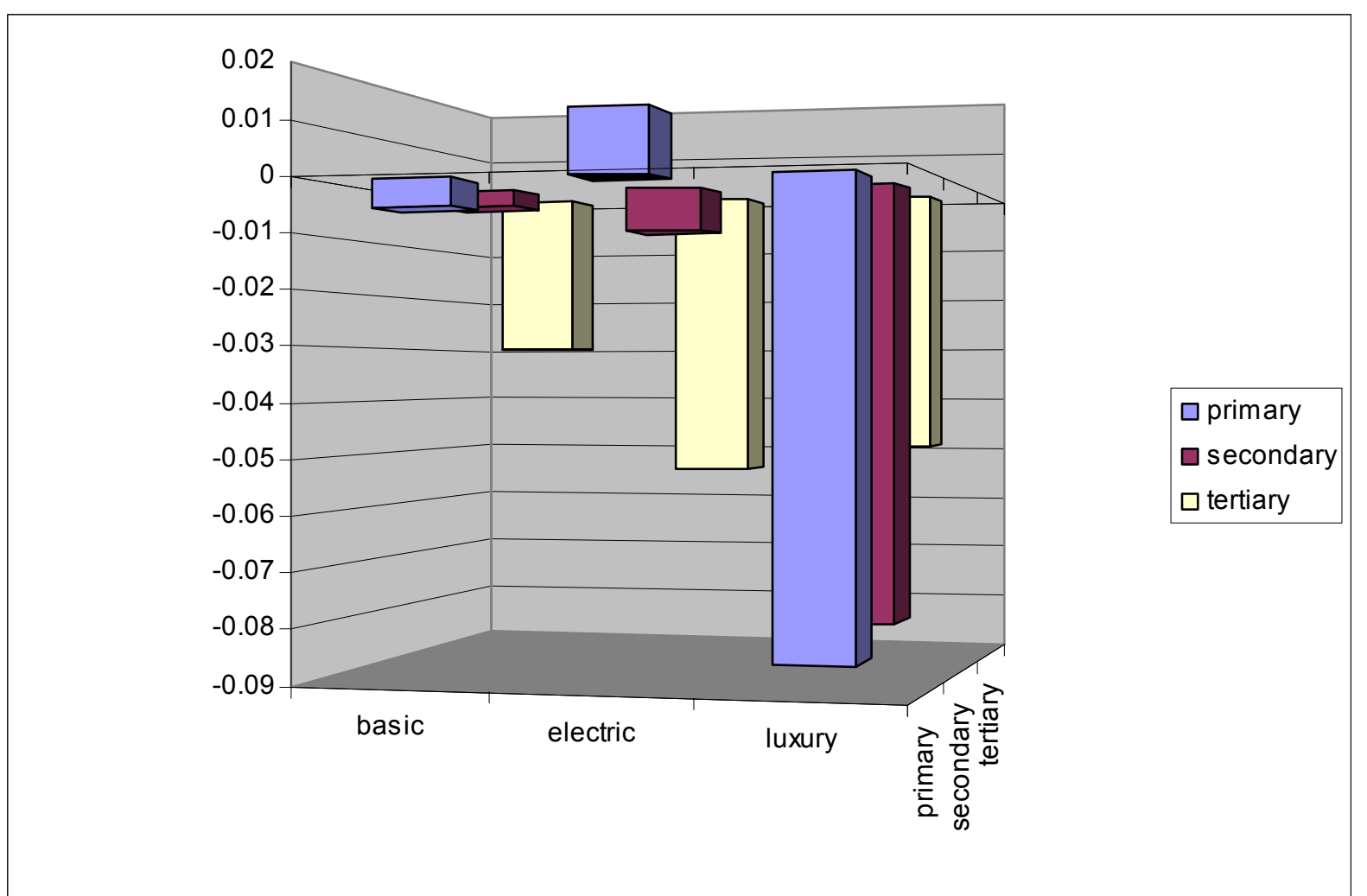

Note: probit weighed regression, including gender, age, age ${ }^{2}$, marital status, employment conditions, opinions about the country situation and the effectiveness of the market, city size, month of interview, country and year dummies. 